\title{
Multi-scale measurements and modeling of denitrification in streams with varying flow and nitrate concentration in the upper Mississippi River basin, USA
}

\author{
John Karl Böhlke • Ronald C. Antweiler • \\ Judson W. Harvey · Andrew E. Laursen • \\ Lesley K. Smith · Richard L. Smith • Mary A. Voytek
}

Received: 31 May 2008/Accepted: 6 October 2008/Published online: 13 January 2009

(C) The Author(s) 2009. This article is published with open access at Springerlink.com

\begin{abstract}
Denitrification is an important net sink for $\mathrm{NO}_{3}{ }^{-}$in streams, but direct measurements are limited and in situ controlling factors are not well known. We measured denitrification at multiple scales over a range of flow conditions and $\mathrm{NO}_{3}{ }^{-}$concentrations in streams draining agricultural land in the upper Mississippi River basin. Comparisons of reach-scale measurements (in-stream mass transport and tracer tests) with local-scale in situ measurements (pore-water profiles, benthic chambers) and laboratory data (sediment core microcosms) gave evidence for heterogeneity in
\end{abstract}

J. K. Böhlke ( $\square)$

US Geological Survey, 431 National Center,

12201 Sunrise Valley Drive, Reston, VA 20192, USA

e-mail: jkbohlke@usgs.gov

R. C. Antweiler · R. L. Smith

US Geological Survey, 3215 Marine St., Boulder, CO 80303, USA

J. W. Harvey · M. A. Voytek

US Geological Survey, 430 National Center, Reston,

VA 20192, USA

A. E. Laursen

Department of Chemistry and Biology, Ryerson

University, 350 Victoria Street, Toronto, ON M5B 2K3,

Canada

\section{K. Smith}

Cooperative Institute for Research in Environmental Sciences, University of Colorado, UCB 216, Boulder, CO 80309-0216, USA factors affecting benthic denitrification both temporally (e.g., seasonal variation in $\mathrm{NO}_{3}{ }^{-}$concentrations and loads, flood-related disruption and re-growth of benthic communities and organic deposits) and spatially (e.g., local stream morphology and sediment characteristics). When expressed as vertical denitrification flux per unit area of streambed $\left(U_{\text {denit }}\right.$, in $\mu$ mol $\mathrm{N} \mathrm{m}^{-2} \mathrm{~h}^{-1}$ ), results of different methods for a given set of conditions commonly were in agreement within a factor of 2-3. At approximately constant temperature $\left(\sim 20 \pm 4^{\circ} \mathrm{C}\right)$ and with minimal benthic disturbance, our aggregated data indicated an overall positive relation between $U_{\text {denit }}(\sim 0-4,000 \mu \mathrm{mol}$ $\left.\mathrm{N} \mathrm{m}^{-2} \mathrm{~h}^{-1}\right)$ and stream $\mathrm{NO}_{3}{ }^{-}$concentration $(\sim 20-$ $1,100 \mu \mathrm{mol} \mathrm{L}{ }^{-1}$ ) representing seasonal variation from spring high flow (high $\mathrm{NO}_{3}{ }^{-}$) to late summer low flow (low $\mathrm{NO}_{3}{ }^{-}$). The temporal dependence of $U_{\text {denit }}$ on $\mathrm{NO}_{3}{ }^{-}$was less than first-order and could be described about equally well with power-law or saturation equations (e.g., for the unweighted dataset, $U_{\text {denit }} \approx$ $26 *\left[\mathrm{NO}_{3}{ }^{-}\right]^{0.44}$ or $U_{\text {denit }} \approx 640 *\left[\mathrm{NO}_{3}{ }^{-}\right] /[180+$ $\mathrm{NO}_{3}{ }^{-}$; ; for a partially weighted dataset, $U_{\text {denit }} \approx$ $14 *\left[\mathrm{NO}_{3}{ }^{-}\right]^{0.54}$ or $U_{\text {denit }} \approx 700 *\left[\mathrm{NO}_{3}{ }^{-}\right] /[320+$ $\left.\mathrm{NO}_{3}{ }^{-}\right]$). Similar parameters were derived from a recent spatial comparison of stream denitrification extending to lower $\mathrm{NO}_{3}{ }^{-}$concentrations (LINX2), and from the combined dataset from both studies over 3 orders of magnitude in $\mathrm{NO}_{3}{ }^{-}$concentration. Hypothetical models based on our results illustrate: (1) $U_{\text {denit }}$ was inversely related to denitrification rate constant $\left(k 1_{\text {denit }}\right.$, in day $\left.{ }^{-1}\right)$ and vertical transfer velocity $\left(v_{\mathrm{f} \text {,denit }}\right.$, 
in $\mathrm{m} \mathrm{day}^{-1}$ ) at seasonal and possibly event time scales; (2) although $k 1_{\text {denit }}$ was relatively large at low flow (low $\mathrm{NO}_{3}{ }^{-}$), its impact on annual loads was relatively small because higher concentrations and loads at high flow were not fully compensated by increases in $U_{\text {denit }}$; and (3) although $\mathrm{NO}_{3}{ }^{-}$assimilation and denitrification were linked through production of organic reactants, rates of $\mathrm{NO}_{3}{ }^{-}$loss by these processes may have been partially decoupled by changes in flow and sediment transport. Whereas $k 1_{\text {denit }}$ and $v_{\text {f,denit }}$ are linked implicitly with stream depth, $\mathrm{NO}_{3}{ }^{-}$concentration, and(or) $\mathrm{NO}_{3}{ }^{-}$load, estimates of $U_{\text {denit }}$ may be related more directly to field factors (including $\mathrm{NO}_{3}{ }^{-}$concentration) affecting denitrification rates in benthic sediments. Regional regressions and simulations of benthic denitrification in stream networks might be improved by including a non-linear relation between $U_{\text {denit }}$ and stream $\mathrm{NO}_{3}{ }^{-}$concentration and accounting for temporal variation.

Keywords Denitrification - Seasonal · Benthic - Hyporheic zone - Isotope tracer . Nitrogen gas $\cdot$ Reach-scale $\cdot$ Microcosm

\section{Introduction}

Denitrification (dissimilatory reduction of nitrate $\left(\mathrm{NO}_{3}{ }^{-}\right)$and nitrite $\left(\mathrm{NO}_{2}{ }^{-}\right)$to nitrous oxide $\left(\mathrm{N}_{2} \mathrm{O}\right)+$ nitrogen gas $\left(\mathrm{N}_{2}\right)$ ) is an important net sink for fixed nitrogen $(\mathrm{N})$ moving through watersheds (Seitzinger et al. 2006). Denitrification within streams and rivers can reduce the total $\mathrm{N}$ load from runoff and groundwater discharge en route to $\mathrm{N}$-sensitive coastal marine environments (Howarth et al. 1996; Alexander et al. 2000; Donner et al. 2004). Quantifying rates and controls of in-stream denitrification is important for rationalizing and predicting effects of land-use changes on downstream ecosystems. Despite its importance and considerable research, methods for measuring in-stream denitrification are difficult and have large uncertainties (Groffman et al. 2006; Birgand et al. 2007), and the controlling variables are not known well enough to make reliable predictions for targeted management decisions (Boyer et al. 2006).

Denitrification in streams typically is associated with benthic sediments, where surface water $\mathrm{NO}_{3}{ }^{-}$is transported by advection and diffusion to sites with bacteria and reactive electron donors and isolated from re-aeration. Fractional losses of stream $\mathrm{NO}_{3}{ }^{-}$by benthic denitrification commonly are relatively high where water depths and $\mathrm{NO}_{3}{ }^{-}$loads are low; therefore, small (low-order) streams are considered to be important sites of net $\mathrm{NO}_{3}{ }^{-}$removal at the watershed scale (Alexander et al. 2000; Seitzinger et al. 2002; Bernot and Dodds 2003; Mulholland et al. 2008). A number of different parameters have been used to express denitrification rates in streams (e.g., Table 1), based on different measurement and modeling approaches (Royer et al. 2004; Wollheim et al. 2006; Mulholland et al. 2008; Alexander et al. 2008b), and uncertainty exists about how best to incorporate denitrification rate measurements in watershed-scale models. Field-based measurements are essential for quantifying process rates under ambient conditions and for detecting flaws in conceptual models, although the inherent variability of natural systems makes it difficult to resolve individual process controls.

Our study was initiated in 1999 to provide field measurements of denitrification and related processes in representative streams draining agricultural land with large $\mathrm{NO}_{3}{ }^{-}$export loads. Measurements were performed by a variety of methods, including ${ }^{15} \mathrm{~N}$ isotopic tracers, at various spatial scales (reach-scale to microcosm), and repeated at different times of year (spring and summer) from 1999 to 2003. Here, we provide a brief overview of results with focus on three major topics: (1) complementary features of different methods; (2) rates and controls of denitrification derived from spatially and temporally distributed measurements; and (3) implications for modeling denitrification in streams with temporally varying flow and $\mathrm{NO}_{3}{ }^{-}$concentration (see also Alexander et al. 2008b).

\section{Study sites}

Our study was conducted in the Iroquois River and one of its tributaries, Sugar Creek, near the IndianaIllinois border (Fig. 1; sample sites IR1-7, SC1-10, T2000, T2003). These streams are in the upper Mississippi River basin within the mid-continent corn-belt, a region that contributes substantially to the $\mathrm{N}$ load delivered by the Mississippi River to the Gulf of Mexico (Goolsby et al. 1999; Alexander et al. 2000; Donner et al. 2004). Land use in the 
Table 1 Parameters and units (modified slightly from Stream-Solute-Workshop 1990)

\begin{tabular}{ll}
\hline$Q$ & Stream flow $\left(\mathrm{m}^{3} \mathrm{~s}^{-1}\right)$ \\
$\mathrm{NO}_{3}{ }^{-}$ & $\mathrm{NO}_{3}{ }^{-}$concentration $\left(\mu \mathrm{mol} \mathrm{N} \mathrm{L}{ }^{-1}\right)$ \\
$r$ & Reaction rate $\left(\mu \mathrm{mol} \mathrm{N} \mathrm{L}{ }^{-1} \mathrm{~h}^{-1}\right)$ \\
$U$ & Reaction rate expressed as vertical reactant flux per unit area $\left(\mu \mathrm{mol} \mathrm{N} \mathrm{m}^{-2} \mathrm{~h}^{-1}\right)$ \\
$v_{\mathrm{f}}$ & Reaction rate expressed as vertical transfer velocity of water column containing reactant $\left(\mathrm{m} \mathrm{h}^{-1}\right.$ or m day $\left.^{-1}\right)$ \\
$k 1$ & \left.${\mathrm{Reaction} \mathrm{rate} \mathrm{constant,} \mathrm{first-order}\left(\mathrm{h}^{-1} \text { or day }\right.}^{-1}\right)$ \\
Subscript denit & $\mathrm{NO}_{3}{ }^{-}$loss by denitrification \\
Subscript NO3T & $\mathrm{Total} \mathrm{NO}_{3}{ }^{-}$loss by denitrification plus other forms of reduction and uptake \\
Subscript NO3T,net & Net total $\mathrm{NO}_{3}{ }^{-}$loss (sum of gains and losses by various processes) \\
\hline
\end{tabular}

Conversions between different expressions of instantaneous rate parameters (used for comparison, with no implication with respect to reaction mechanism or rate law)

$U=r *$ depth
$v_{\mathrm{f}}=U / \mathrm{NO}_{3}{ }^{-}$
$k 1=v_{\mathrm{f}} /$ depth
$k 1=r / \mathrm{NO}_{3}^{-}$

Fig. 1 Map of the Iroquois River basin (dashed outline) showing sampling sites along the Iroquois River (IR) and Sugar Creek (SC). IR1-7 and SC1-10 are locations of Lagrangian reach-scale $\mathrm{NO}_{3}{ }^{-}$and $\mathrm{N}_{2}$ mass balance water samples and cores used in laboratory microcosms. T2001 and T2003 are locations of reach-scale isotope tracer experiments and associated hyporheic-zone profiles. In situ chambers were installed at SC3 and T2003

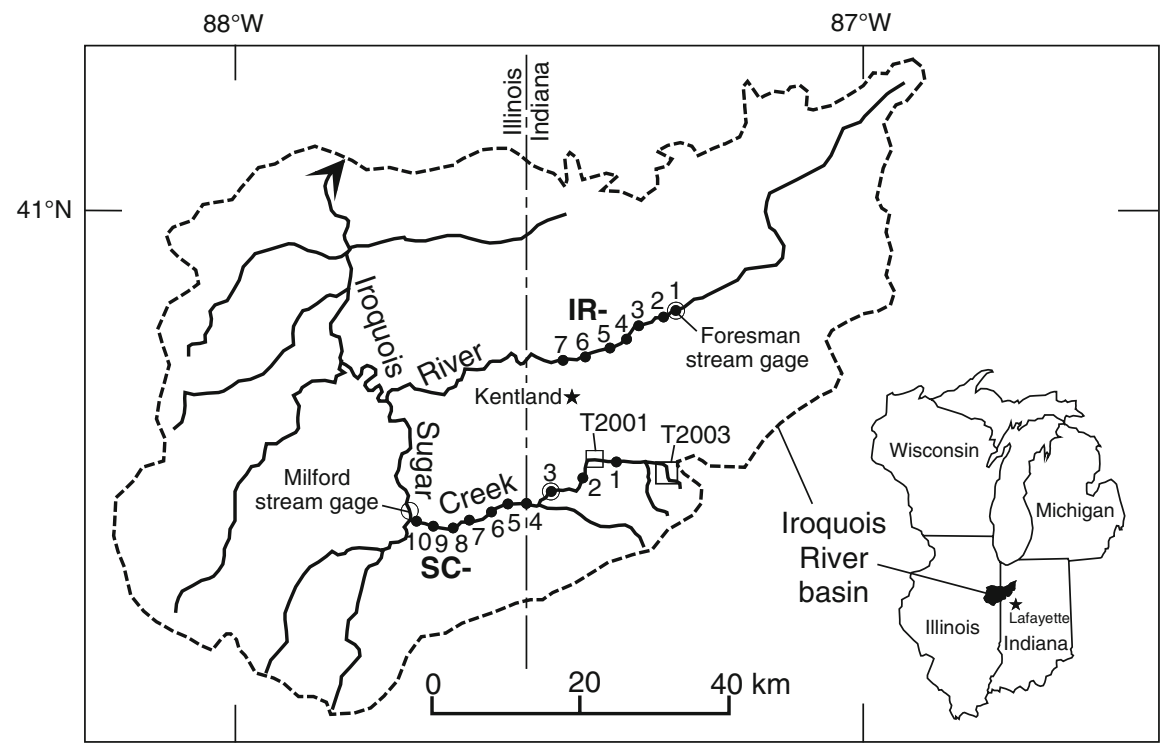

contributing watersheds was $90-100 \%$ agriculture, mainly corn and soybean rotations. Underground tile drains were common, and the stream channels were modified locally by dredging. The Iroquois River reach generally was deeper and more turbid than the Sugar Creek reach, with relatively uniform finegrained bottom sediment. In comparison, the Sugar Creek reach was shallower, with more variable bottom sediments and local geomorphology (pools and riffles), and clearer water at low flow in its upper reaches. Upper reaches of Sugar Creek (above site $\mathrm{SC} 4)$ were gaining flow measurably $\left(>2 \% \mathrm{~km}^{-1}\right.$ between sites $4-5 \mathrm{~km}$ apart) by ground-water discharge, whereas lower reaches of Sugar Creek and most of the Iroquois River reaches did not gain measurably except from tributaries (Antweiler et al. 2005c).

Iroquois River and Sugar Creek exhibited seasonal variations in base flow, punctuated by within-season peak flow events (Fig. 2). $\mathrm{NO}_{3}^{-}$concentrations in Iroquois River and Sugar Creek varied seasonally from $>1,000 \mu \mathrm{mol} \mathrm{L}^{-1}\left(>14 \mathrm{mg} \mathrm{N} \mathrm{L}^{-1}\right) \quad$ during high-flow periods, mainly in winter and spring, to $<100 \mu \mathrm{mol} \mathrm{L}^{-1}\left(<1.4 \mathrm{mg} \mathrm{N} \mathrm{L}^{-1}\right)$ during low flow 


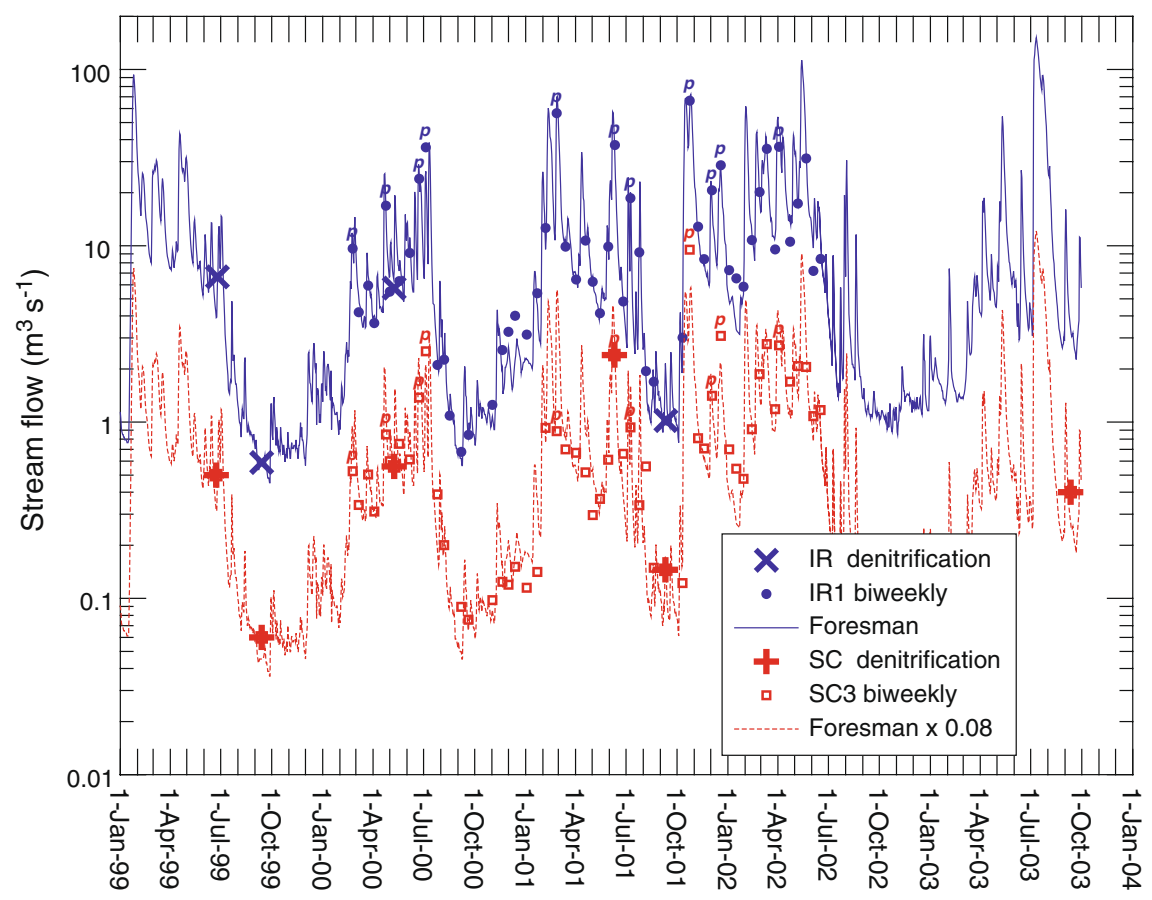

Fig. 2 Recorded stream flow at IR1 (Iroquois River) and estimated flow at SC3 (Sugar Creek), showing dates of denitrification measurements and other stream samples. Small symbols indicate dates of monitoring samples collected approximately biweekly ( 2 times per month) at sites IR1 and SC3 (Fig. 1) between February 2000 and June 2002 (Antweiler et al. 2005b), with " $p$ " highlighting near peak-flow conditions

periods, mainly in late summer and fall, based on biweekly (2 times per month) monitoring at IR1 and SC3 from February 2000 to June 2002 (Antweiler et al. 2005b) (Fig. 3). At any given time, $\mathrm{NO}_{3}{ }^{-}$ concentrations at IR1 and SC3 were approximately the same, whereas the flow at IR1 was approximately 10 times the flow at SC3 (Fig. 3). $\mathrm{NO}_{3}{ }^{-}$was the dominant $\mathrm{N}$ species throughout the year in both streams (Antweiler et al. 2005b) (Fig. 4). Mean concentrations $( \pm 1 \sigma)$ of reduced $\mathrm{N}$ species in biweekly samples from 2000 to 2002 were: at SC3, $\mathrm{NH}_{4}{ }^{+}=4 \pm 3 \mu \mathrm{mol} \mathrm{L}{ }^{-1}$ and particulate organic $\mathrm{N}$ $(\mathrm{PON})=4 \pm 3 \mu \mathrm{mol} \mathrm{L}{ }^{-1}$; at IR1, $\mathrm{NH}_{4}{ }^{+}=9 \pm 6$ $\mu \mathrm{mol} \mathrm{L}{ }^{-1}$ and $\mathrm{PON}=16 \pm 9 \mu \mathrm{mol} \mathrm{L}{ }^{-1}$.

\section{Methods}

We used multiple approaches at various spatial scales under different flow conditions in Iroquois River and Sugar Creek to measure in-stream denitrification during runoff events. Large symbols indicate dates of denitrification measurements. The continuous stream flow curve for IR1 is equal to the daily discharge record at the USGS stream gage at Foresman, Indiana (USGS 05524500) (USGS 2008). The curve for SC3 is equal to 0.08 times the Foresman flow, based on a correlation between measured flows at IR1 and SC3 for the biweekly sample dates

and(or) $\mathrm{N}$ loss rates, evaluate biases and uncertainties, derive complementary information, and increase confidence in the overall estimates. Most of the methods described here were based on production of $\mathrm{N}_{2}$, with or without ${ }^{15} \mathrm{~N}$ isotopic tracers, although reach-scale $\mathrm{NO}_{3}{ }^{-}$fluxes are included for comparison. We equate $\mathrm{N}_{2}$ production with denitrification, as our measurements were not designed to evaluate other potential $\mathrm{N}_{2}$-producing processes such as anammox. Detailed descriptions of methods are given elsewhere (Laursen and Seitzinger 2002; Böhlke et al. 2004; Antweiler et al. 2005b; Antweiler et al. 2005c; Smith et al. 2006; Smith et al. submitted; Tobias et al. submitted). In general, we used methods that involved minimal disturbance of the ambient $\mathrm{NO}_{3}{ }^{-}$ concentrations, microbial communities, and sediment structure. Regardless of the method, however, there were inherent complications with measurements in small streams owing to heterogeneous morphology, rapidly changing hydraulic conditions, substantial hyporheic flow, rapid air-water exchange, and 


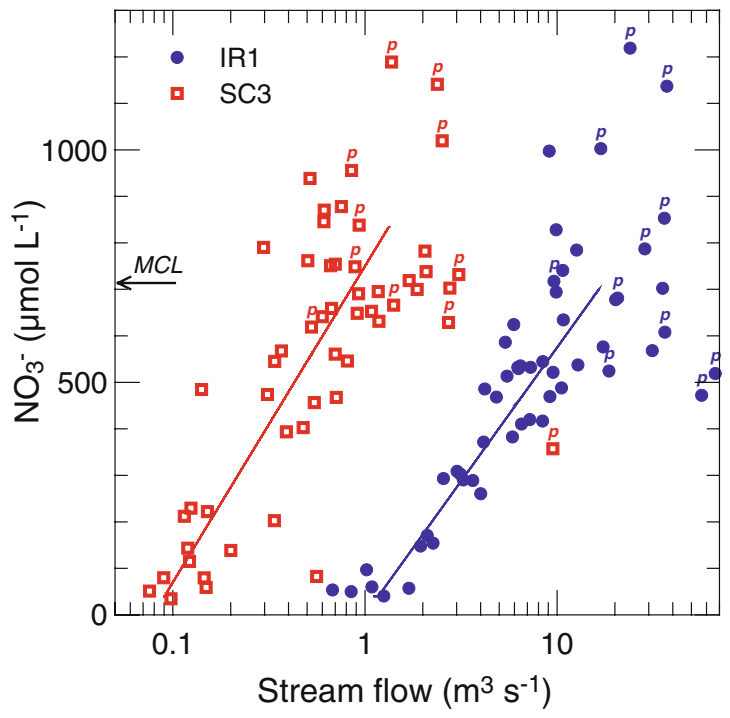

Fig. 3 Variations in stream flow and $\mathrm{NO}_{3}{ }^{-}$concentration at IR1 (Iroquois River) and SC3 (Sugar Creek). Symbols represent samples collected approximately biweekly between February 2000 and June 2002, representing a range of flow conditions (Fig. 2). Curves indicate trends used to approximate seasonal variations in base flow. Samples labeled " $p$ " were collected near peak flow during runoff events (Fig. 2), when $\mathrm{NO}_{3}{ }^{-}$concentrations may have been anomalously high or low, depending on precipitation intensity and antecedent conditions. "MCL" is the maximum contaminant level for $\mathrm{NO}_{3}{ }^{-}$in drinking water in the USA $\left(714 \mu \mathrm{mol} \mathrm{L}^{-1}\right.$, or $\left.10 \mathrm{mg} \mathrm{N} \mathrm{L}^{-1}\right)$

varying ground-water inputs, some of which yielded uncertainties that were difficult to quantify. Major features of each method are summarized briefly (listed in order from large-scale to small-scale).

Reach-scale methods

\section{Reach $\mathrm{NO}_{3}^{-}$}

Lagrangian sampling and flow measurements followed changes in $\mathrm{NO}_{3}{ }^{-}$concentrations and loads of stream parcels moving downstream past a number of sampling sites (Fig. 1) covering about 2-3 days of travel time (about 10-20 km) (Antweiler et al. 2005c). In principle, this method gave definitive results with respect to net $\mathrm{NO}_{3}{ }^{-}$mass gains or losses when done precisely with fully integrated sampling procedures (Goolsby et al. 2000; Antweiler et al. 2005c); however, it could not resolve individual processes leading to offsetting combinations of regeneration (nitrification) and loss (denitrification, assimilation, or reduction to ammonium $\left.\left(\mathrm{NH}_{4}{ }^{+}\right)\right)$. Net

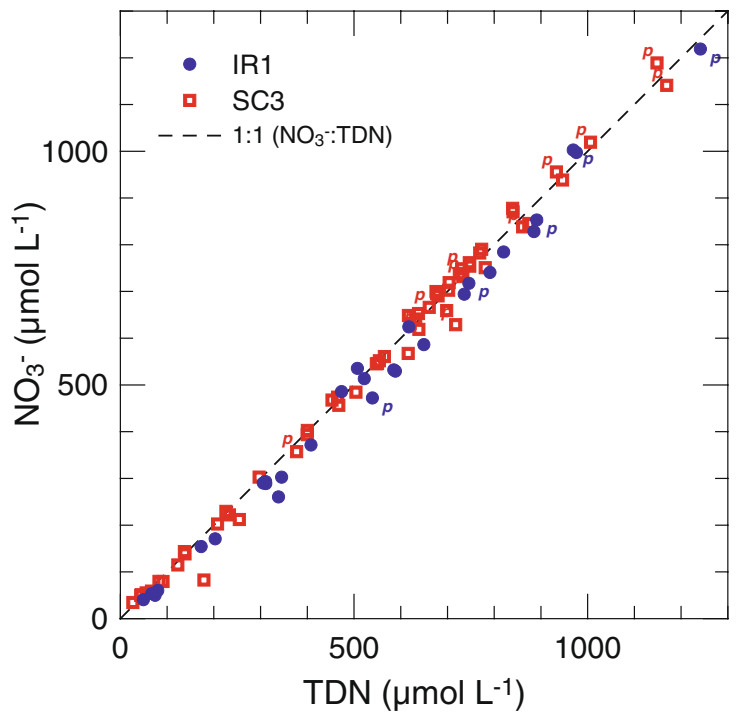

Fig. 4 Relation between $\mathrm{NO}_{3}{ }^{-}$and total dissolved $\mathrm{N}$ (TDN $\left.=\mathrm{NO}_{3}{ }^{-}+\mathrm{NO}_{2}{ }^{-}+\mathrm{NH}_{4}{ }^{+}+\mathrm{DON}\right)$ for biweekly stream samples collected at IR1 and SC3, representing a range of flow conditions (see Figs. 2, 3). TDN analyses were performed by high-temperature combustion and oxidation, whereas $\mathrm{NO}_{3}{ }^{-}$analyses were performed by ion chromatography (Antweiler et al. 2005b). Samples labeled " $p$ " were collected near peak flow during runoff events (Fig. 2). Deviations from the 1:1 line are minimal, indicating $\mathrm{NO}_{3}{ }^{-}$ was the dominant dissolved $\mathrm{N}$ species in all sampled flow conditions

$\mathrm{NO}_{3}{ }^{-}$losses were estimated from changes in $\mathrm{NO}_{3}{ }^{-}$ concentrations through reaches in which changes in flow resulting from tributary input or direct groundwater discharge were not measurable $(<5 \%$ change between sample locations). Stream depths, flows, and velocities were estimated from integrated crosssection measurements, in some cases with additional data from rhodamine dye tracers. Sources of error included measurements of $\mathrm{NO}_{3}{ }^{-}$concentrations ( $\pm 4 \%)$, mean depth $( \pm 10 \%)$, and mean transport velocity ( $\pm 10-20 \%$, depending if based on tracers or cross-sectional velocities). This method also was affected by temporal changes in flows and concentrations not related to local in-stream processes (including diel cycles or aperiodic interruptions by precipitation events with subsequent flow recessions).

\section{Reach $\mathrm{N}_{2}$}

Lagrangian stream sampling and high-precision measurements of $\mathrm{N}_{2}$ and argon (Ar) concentrations by membrane inlet mass spectrometry (MIMS) were 
combined with gas flux simulation models to determine net $\mathrm{N}_{2}$ production rates at the reach scale (Laursen and Seitzinger 2002). In principle, this method provided in situ estimates of total denitrification (including coupled nitrification/denitrification) at a scale comparable to the Lagrangian $\mathrm{NO}_{3}{ }^{-}$mass balance. $\mathrm{N}_{2}$ fluxes were simulated at 1-min time steps with input parameters including measured concentration, water temperature, stream depth and velocity, atmospheric pressure, and air-water gas transfer velocity (GTV). Values of GTV were determined by applying dual-gas tracers within a day or two of the Lagrangian $\mathrm{N}_{2}+$ Ar sampling. Uncertainties in modeled denitrification rates were estimated by combining uncertainties in $\mathrm{N}_{2}$ concentration $( \pm 0.1 \%)$, depth $( \pm 10 \%)$, pressure $( \pm 0.1 \mathrm{kPa})$, GTV $( \pm 25 \%)$, and Schmidt number conversion coefficient for different gases $(-2 / 3$ to $-1 / 2)$ to give minimum and maximum results. In situations with relatively low $\mathrm{N}_{2}$ production rates, short intervals between Lagrangian sampling points, or rapid air-water exchange, $\mathrm{N}_{2}$ concentrations were not elevated sufficiently to detect denitrification components reliably (Laursen and Seitzinger 2005). In addition, there were other potential sources of excess $\mathrm{N}_{2}$ such as air bubble entrainment at the stream surface and discharge of $\mathrm{N}_{2}$-rich ground water, and there was a possibility of $\mathrm{N}_{2}$ stripping by gas bubbles formed during photosynthesis, denitrification, or methanogenesis.

Reach ${ }^{15} \mathrm{~N}_{2}$

Reach-scale in-stream tracer experiments with bromide $\left(\mathrm{Br}^{-}\right)$and isotopically labeled $\mathrm{NO}_{3}{ }^{-}\left({ }^{15} \mathrm{NO}_{3}{ }^{-}\right)$ were conducted in low-flow conditions in September 2001 and September 2003 to determine in situ rates of denitrification and other $\mathrm{N}$ cycling processes in stream parcels moving downstream past sampling sites, covering about $8-20 \mathrm{~h}$ of travel time (about 1-3 km). Downstream loss of tracer ${ }^{15} \mathrm{NO}_{3}{ }^{-}$yielded total $\mathrm{NO}_{3}{ }^{-}$loss rate, and accumulation of ${ }^{15} \mathrm{~N}_{2}$ was modeled to quantify denitrification of surface-water $\mathrm{NO}_{3}{ }^{-}$where total chemical flux changes were not usable because of compensating gains and losses or overall insensitivity (Böhlke et al. 2004). Mean tracer velocity and travel time were estimated by modeling $\mathrm{Br}^{-}$breakthrough curves using the OTIS-P program (Runkel 1998). Reaction rates were modeled as vertical fluxes into, and out of, a vertically mixed water column that traversed the tracer reach after the tracers reached near-steady-state plateau values, with measurements at multiple sampling sites as target values in a time-forward simulation (Böhlke et al. 2004). Estimated uncertainties in $U_{\text {denit }}$ were $\pm 25 \%$, based on analytical uncertainties and multiple simulations in which target concentrations and isotope values were held constant while varying denitrification rates and gas transfer velocities within reasonable limits, but do not reflect errors associated with estimated mean stream depth and velocity. Our 2003 tracer experiment included a simultaneous continuous $\mathrm{SF}_{6}$ injection for real-time gas transfer data (Tobias et al. submitted), but additional uncertainty remained in the conversion of $\mathrm{GTV}_{\mathrm{SF} 6}$ to $\mathrm{GTV}_{\mathrm{N} 2}$ (Asher and Wanninkhof 1998). The surfacewater response model required that tracer ${ }^{15} \mathrm{NO}_{3}{ }^{-}$ efficiently replaced non-tracer $\mathrm{NO}_{3}{ }^{-}$at active reaction sites, which required tracer injections to be long compared to stream-water residence times in the reactive parts of the hyporheic zone. Tightly coupled nitrification-denitrification involving non-tracer $\mathrm{NO}_{3}{ }^{-}$production and reduction within the hyporheic zone would not be detected directly by this method.

Local in situ methods

Hyporheic ${ }^{15} \mathrm{~N}_{2}$

Measurements of tracer $\mathrm{Br}^{-},{ }^{15} \mathrm{NO}_{3}{ }^{-}$, and ${ }^{15} \mathrm{~N}_{2}$ in pore-water profiles within the hyporheic zone during in-stream tracer tests in September 2001 and September 2003 provided direct in situ measures of denitrification rates integrated along subsurface flow paths (Harvey et al. 2005). The ${ }^{15} \mathrm{NO}_{3}{ }^{-}$measurements also indicated the magnitude of coupled nitrification-denitrification within the hyporheic zone. Hyporheic-zone profiles were sampled using a USGS MINIPOINT sampler, which removed porewater by pumping at low flow rate from a fixed array of small diameter tubes at 6 depths from 1.5 to $15 \mathrm{~cm}$ below the sediment-water interface (Harvey and Fuller 1998). Air-water gas exchange was assumed to be negligible in water parcels following interstitial flow paths from the sediment-water interface to the sampling ports, but subsurface mixing with discharging ground water (containing excess $\mathrm{N}_{2}$ but no $\mathrm{NO}_{3}{ }^{-}$) was an important feature of the calculations. Estimated overall uncertainties were $\pm 30 \%$, based 
on previous uncertainty estimates for tracer-based determinations of hyporheic-zone processes (Harvey and Fuller 1998) combined with uncertainties in isotopic measurements. Vertically integrated denitrification rates derived from tracer data in selected profiles were compared with reach-scale rates to determine the contribution of hyporheic-zone denitrification to overall reach-scale denitrification (Harvey et al. 2005). These determinations were reliable only when concentration gradients of tracer reactants and products were near steady-state within the hyporheic zone, which required many hours of preceding steady tracer flow in the overlying surface water. As with other small-scale methods, hyporheiczone results from a limited number of sites may have been biased if they did not provide proportional representation of stream-bed heterogeneity.

\section{Chamber ${ }^{15} \mathrm{~N}_{2}$}

Benthic chambers (dome-shaped mesocosms) emplaced on the stream bottom were used to determine in situ rates of denitrification and other $\mathrm{N}$-cycle processes with $\mathrm{Br}^{-}$and various ${ }^{15} \mathrm{~N}$ tracers (Smith et al. 2005; submitted). Chambers were designed to keep the in situ sediment-water interface intact. Clear plastic walls permitted near-natural light penetration, and internal mixing minimized surface-water gradients. Two chamber sizes were used, enclosing either 11 or $55 \mathrm{~L}$ of surface water and covering approximately 0.11 or $0.29 \mathrm{~m}^{2}$ of stream bottom, respectively. Both chamber sizes were large compared to core samples, but small in the context of a heterogeneous stream reach. Chambers permitted manipulations that were difficult to accomplish at larger scales, such as ${ }^{15} \mathrm{~N}$ additions as $\mathrm{NO}_{3}{ }^{-}, \mathrm{NO}_{2}{ }^{-}$, and $\mathrm{NH}_{4}{ }^{+}$. They also permitted monitoring of shortterm $(0-10 \mathrm{~h})$ or diel variations in systems closed to air-water gas exchange, but otherwise relatively undisturbed. However, in situ chambers may have promoted or inhibited local hyporheic exchange by altering hydraulic gradients, and conditions within them may have evolved chemically in ways different from the external environment. Estimated uncertainties of chamber denitrification rates were $\pm 15 \%$, based on analytical uncertainties and best-fit, multiple simulations of concentrations and isotopic compositions through reaction time courses.
Laboratory methods

Core $\mathrm{N}_{2}$ and core ${ }^{15} \mathrm{~N}_{2}$

Laboratory incubations were performed with intact sediment cores and overlying surface water (also termed "microcosms"), with and without ${ }^{15} \mathrm{NO}_{3}{ }^{-}$ tracer, to determine rates of benthic denitrification (Smith et al. 2006). The sediment-water interface in the core microcosms had a surface area of $0.005 \mathrm{~m}^{2}$. Surface water was pumped slowly through the upper parts of the core barrels above the sediment-water interface while being stirred, with steady-state surface-water residence times of about $4-8 \mathrm{~h}$ to allow accumulation of measurable $\mathrm{N}_{2}$. Denitrification rates were determined independently from two different sets of measurements on surface water entering and leaving the core microcosms. Membrane-inlet mass spectrometry (MIMS) provided total accumulation rates of $\mathrm{N}_{2}$ in surface water overlying the sedimentwater interface. Isotope-ratio mass spectrometry (IRMS) provided accumulation rates of $\mathrm{N}_{2}$ produced by reduction of ${ }^{15} \mathrm{~N}$ labeled surface-water $\mathrm{NO}_{3}{ }^{-}$. Measurement uncertainties were approximately $\pm 50-140 \mu \mathrm{mol} \mathrm{m}{ }^{-2} \mathrm{~h}^{-1}$ for MIMS (based on reproducibility of blanks) and the larger of $\pm 8 \mu \mathrm{mol}$ $\mathrm{m}^{-2} \mathrm{~h}^{-1}$ or $\pm 5 \%$ of the $U_{\text {denit }}$ value for IRMS (based on reproducibility of ${ }^{15} \mathrm{~N}$ measurements) (Smith et al. 2006). Comparison of $\mathrm{N}_{2}$ (MIMS) and ${ }^{15} \mathrm{~N}_{2}$ (IRMS) results provided evidence about the relative importance of surface-water $\mathrm{NO}_{3}{ }^{-}$and new $\mathrm{NO}_{3}{ }^{-}$ produced by nitrification as reactants for denitrification. Core microcosms also permitted manipulations such as $\mathrm{NO}_{3}{ }^{-}$additions. Hyporheic exchange was limited to that induced by stirring of the water column. Applying microcosm results at the reach scale was subject to bias because of the small surface area of the cores and local heterogeneity of the stream bed (Voytek et al. 2001).

\section{Summary of results}

Results are summarized in Figs. 5 and 6, and a list of rates and uncertainties for different methods is given in Table 2. Most measurements were performed at relatively constant temperatures $\left(20 \pm 4^{\circ} \mathrm{C}\right)$, but under varying flow conditions and $\mathrm{NO}_{3}{ }^{-}$concentrations: (1) high base flow and high $\mathrm{NO}_{3}{ }^{-}$in late 
Fig. 5 Vertical $\mathrm{N}$ fluxes representing denitrification $\left(U_{\text {denit }}\right)$ or net $\mathrm{NO}_{3}{ }^{-}$loss $\left(U_{\mathrm{NO} 3 \mathrm{~T}, \text { net }}\right.$, for reach $\mathrm{NO}_{3}{ }^{-}$ only) versus $\mathrm{NO}_{3}{ }^{-}$

concentrations, measured by various methods. $S C$

Sugar Creek (open symbols); IR Iroquois River (solid symbols). Symbols are in color for ${ }^{15} \mathrm{~N}$ isotope tracer results. Symbol size is related to the scale of the measurement. Estimated uncertainties are as shown for reach $\mathrm{NO}_{3}{ }^{-}$and reach $\mathrm{N}_{2}$ methods, $\pm 25 \%$ for reach ${ }^{15} \mathrm{~N}_{2}, \pm 30 \%$ for hyporheic ${ }^{15} \mathrm{~N}_{2}, \pm 15 \%$ for chamber ${ }^{15} \mathrm{~N}_{2}, \pm 50$ $140 \mu \mathrm{mol} \mathrm{m} \mathrm{m}^{-2} \mathrm{~h}^{-1}$ for core $\mathrm{N}_{2}$, and $\pm 5 \%$ for core ${ }^{15} \mathrm{~N}_{2}$. Heavy curves are fits to the $U_{\text {denit }}$ data, using Eqs. 1 (saturation) and 2 (power law), with and without weighting of the data (see text for parameters). a $U_{\text {denit }}$ and $U_{\mathrm{NO} 3 \mathrm{~T} \text {, net }}$ measurements at ambient $\mathrm{NO}_{3}{ }^{-}$concentrations, with fits to $U_{\text {denit }}$ data. b $U_{\text {denit }}$ from $\mathrm{NO}_{3}{ }^{-}$addition experiments (arrows connect results from chambers and core microcosms before and after $\mathrm{NO}_{3}{ }^{-}$addition); fits from (a) are shown for reference. c $U_{\text {denit }}$ measurements at ambient $\mathrm{NO}_{3}{ }^{-}$concentrations, plus reach-scale denitrification data and fit from LINX2 (Mulholland et al. 2008), with additional fits to the combined data (unweighted)

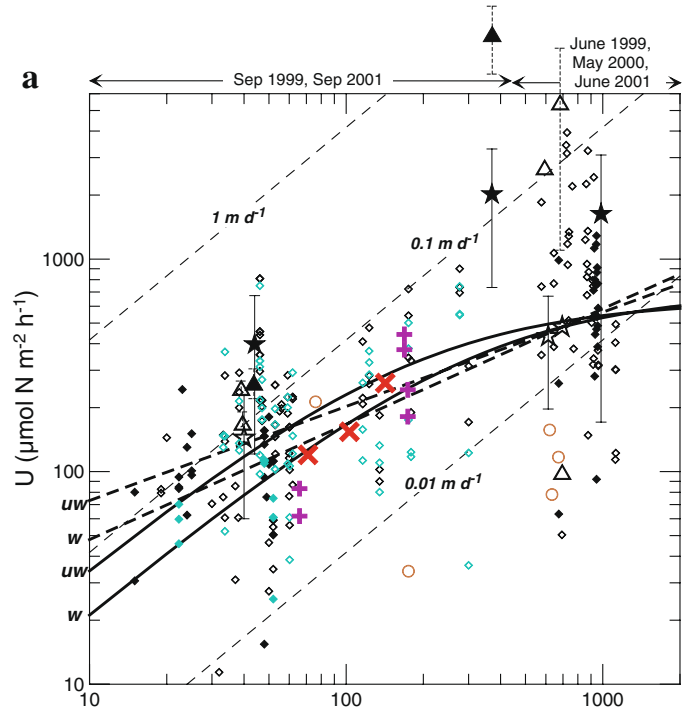

Ambient $\mathrm{NO}_{3}$

$\triangle$ Reach $\mathrm{NO}_{3}{ }^{-}(\mathrm{SC})$

Reach $\mathrm{NO}_{3}{ }^{-}(\mathrm{IR})$

$\star$ Reach N $N_{2}$ (IR)

Reach ${ }^{15} \mathrm{~N}_{2}$ (SC)

+ Hyporheic ${ }^{15} \mathrm{~N}_{2}$ (SC)

- Chamber ${ }^{15} \mathrm{~N}_{2}$ (SC)

- Core $\mathrm{N}_{2}$ (SC)

- Core $\mathrm{N}_{2}(\mathrm{IR})$

- Core ${ }^{15} \mathrm{~N}_{2}(\mathrm{SC})$

- Core ${ }^{15} \mathrm{~N}_{2}$ (IR) Saturation fit

- uw = unweighted $w=$ weighted Power law fit

Power law fit
- $\quad$ uw $=$ unweighted $w=$ weighted

_ - - Line of constant $v_{f}$

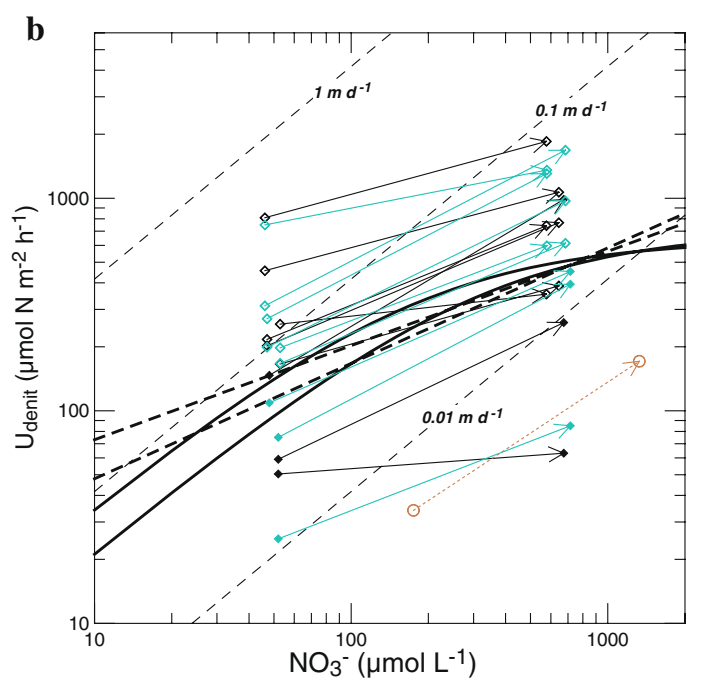

$\mathrm{NO}_{3}{ }^{-}$additions (fits from A)

$\odot$ Chamber ${ }^{15} \mathrm{~N}_{2}\left(\mathrm{SC},+\mathrm{NO}_{3}{ }^{2}\right)$ $\leadsto$ Core $\mathrm{N}_{2}\left(\mathrm{SC},+\mathrm{NO}_{3}{ }^{-}\right)$ $\rightarrow$ Core $\mathrm{N}_{2}\left(\mathrm{IR},+\mathrm{NO}_{3}{ }^{-}\right)$ $\leadsto$ Core ${ }^{15} \mathrm{~N}_{2}\left(\mathrm{SC},+\mathrm{NO}_{3}{ }^{-}\right)$ $\rightarrow$ Core ${ }^{15} \mathrm{~N}_{2}\left(\mathrm{IR},+\mathrm{NO}_{3}{ }^{-}\right)$

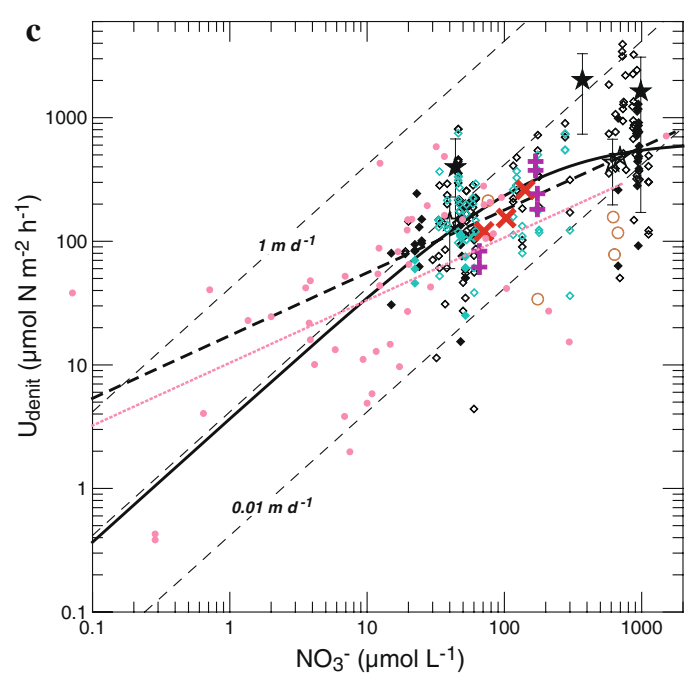

Ambient $\mathrm{NO}_{3}{ }^{-}$

Reach $\mathrm{N}_{2}$ (SC)

$\star$ Reach $\mathrm{N}_{2}$ (IR)

X Reach ${ }^{15} \mathrm{~N}_{2}$ (SC)

+ Hyporheic ${ }^{15} \mathrm{~N}_{2}$ (SC)

- Chamber ${ }^{15} \mathrm{~N}_{2}(\mathrm{SC})$

- Core $\mathrm{N}_{2}(\mathrm{SC})$

- Core $\mathrm{N}_{2}$ (IR)

- Core ${ }^{15} \mathrm{~N}_{2}$ (SC)

- Core ${ }^{15} \mathrm{~N}_{2}$ (IR)

- LINX2 data LINX2 fit

- Saturation fit (USGS+LINX2) - - - Power law fit (USGS+LINX2) --- Line of constant $v_{f}$ 

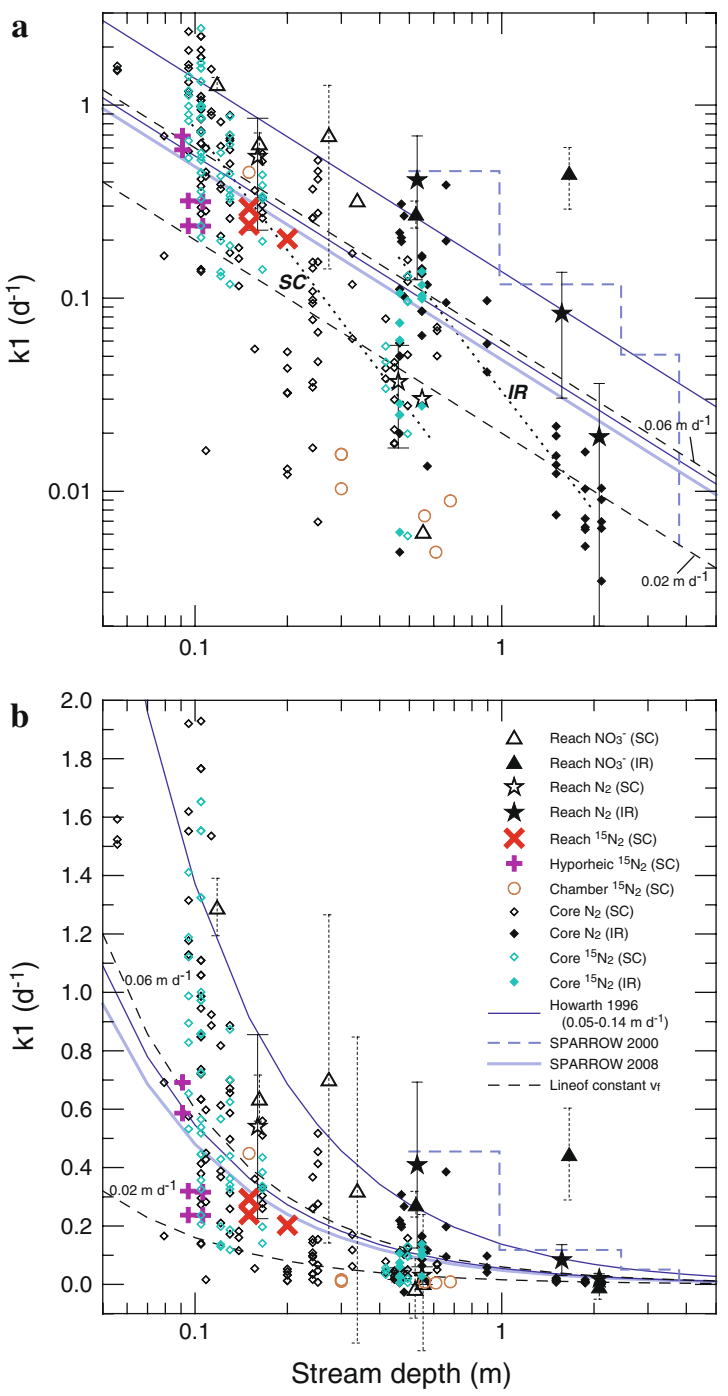

Fig. 6 First-order rate constants representing denitrification $\left(k 1_{\text {denit }}\right)$ or net $\mathrm{NO}_{3}{ }^{-}$loss $\left(k 1_{\mathrm{NO} 3 \mathrm{~T} \text {,net }}\right.$, for reach $\mathrm{NO}_{3}{ }^{-}$only $)$ versus stream depth, measured by various methods, including $\mathrm{NO}_{3}{ }^{-}$addition experiments. SC Sugar Creek (open symbols); $I R$ Iroquois River (solid symbols). Symbols are in color for ${ }^{15} \mathrm{~N}$ isotope tracer results. Symbol size is related to the scale of the measurement. Stream depths in this plot are mean depths for measured cross sections in the vicinity of hyporheic-zone profiles and cores taken for laboratory microcosms. Data from the current study are compared with regional estimates for watersheds around the north Atlantic Ocean (Howarth et al. 1996) and regression results from the inverse SPARROW model for the Mississippi River basin (Alexander et al. 2000; Alexander et al. 2008a). Lines of constant $v_{\mathrm{f}, \text { denit }}$ at 0.02 and $0.06 \mathrm{~m} \mathrm{day}^{-1}$ would result from independent fits to our data from May to June and September, respectively (Fig. 5), and are shown for comparison only. a Log plot, showing all data. En echelon trends followed by data from IR and SC are highlighted qualitatively with dotted lines. b Log-linear plot, showing all data spring-early summer (June 1999, May 2000, June 2001); and (2) low base flow and low $\mathrm{NO}_{3}{ }^{-}$in late summer (September 1999, September 2001, September 2003). Parameters and symbols used in this paper (Table 1) are similar to those suggested by the Stream Solute Workshop (1990). The primary unit for expressing results in figures and tables is the vertical flux $\left(U\right.$, in $\mu$ mol $\left.\mathrm{N} \mathrm{m}^{-2} \mathrm{~h}^{-1}\right)$. Whereas the small-scale enclosure-type methods yielded $U$ values directly, large-scale methods yielded rates that were converted to $U$ values based on measurements of stream geometry and flow. Estimates of uncertainties (Table 2) were based in part on measurement errors, but they do not consistently reflect the full range of possible uncertainties in parameters such as stream depth and velocity, nor do they account fully for transient flows and diel processes.

Reach-scale results

\section{Reach $\mathrm{NO}_{3}{ }^{-}$}

Reach-scale mass-balance estimates of net $\mathrm{NO}_{3}{ }^{-}$loss were made only in stream reaches (IR1-7, SC4-10) with no detectable inflow ( $\pm 5 \%$ change in flow) other than measured tributaries. In upper Sugar Creek (SC1-4), the reach $\mathrm{NO}_{3}{ }^{-}$approach was not useful for estimating in-stream processes because $\mathrm{NO}_{3}{ }^{-}$loads were augmented by ground-water inflows with unknown composite $\mathrm{NO}_{3}{ }^{-}$concentrations (Böhlke et al. 2004; Antweiler et al. 2005c). From measured $\mathrm{NO}_{3}{ }^{-}$concentration changes in reaches with nondetectable changes in flow, we calculated apparent net $\mathrm{NO}_{3}{ }^{-}$losses $\left(U_{\mathrm{NO} 3 \mathrm{~T}, \text { net }}\right)$ ranging from -70 to $+11,000 \mu \mathrm{mol} \mathrm{m}{ }^{-2} \mathrm{~h}^{-1}$, with a weak overall positive correlation between $U_{\mathrm{NO} 3 \mathrm{~T} \text {, net }}$ and $\mathrm{NO}_{3}{ }^{-}$(Fig. 5a). However, many calculated values were indistinguishable from 0 when assigned typical uncertainties in the $\mathrm{NO}_{3}{ }^{-}$analyses $( \pm 4 \%)$, and all but a few were suspect when evaluated as loads because of uncertainties in flow measurements. Furthermore, by combining diel fixed-site sampling with the Lagrangian sampling (Antweiler et al. 2005a; Antweiler et al. 2005c), we documented substantial rapid temporal changes in flow and $\mathrm{NO}_{3}{ }^{-}$caused by high-flow events and subsequent recessions. Rapid temporal changes at fixed sites implied that downstream changes at Lagrangian sites were difficult to resolve clearly, even with relatively minor errors in travel times and 
Table 2 Overview of rates and selected sources of uncertainty

\begin{tabular}{|c|c|c|c|c|c|c|}
\hline Method & $\begin{array}{l}\text { Median } \\
U \mu \mathrm{mol} \\
\mathrm{m}^{-2} \mathrm{~h}^{-1}\end{array}$ & $\begin{array}{l}\text { Median } \pm U^{\mathrm{a}} \\
(\%)\end{array}$ & $\begin{array}{l}\text { Range of } \\
U \mu \mathrm{mol} \\
\mathrm{m}^{-2} \mathrm{~h}^{-1}\end{array}$ & $\begin{array}{l}\text { Range of } \pm \\
U^{\mathrm{b}} \mu \mathrm{mol} \\
\mathrm{m}^{-2} \mathrm{~h}^{-1}\end{array}$ & $\begin{array}{l}\text { Major } \\
\text { uncertainties } \\
\text { included in } U^{\text {c }}\end{array}$ & $\begin{array}{l}\text { Approximate } \\
\text { uncertainties } \\
\text { not included }^{\mathrm{c}}\end{array}$ \\
\hline \multicolumn{7}{|l|}{ Reach scale } \\
\hline Reach $\mathrm{NO}_{3}^{-}$ & 248 & 80 & $0-11,500$ & $19-4,400$ & $\mathrm{NO}_{3}^{-}( \pm 4 \%)$ & $\begin{array}{l}D( \pm 10 \%) \\
W( \pm 20 \%) \\
V( \pm 20 \%)\end{array}$ \\
\hline Reach $\mathrm{N}_{2}$ & 456 & 67 & $144-2,015$ & $84-1,458$ & $\begin{array}{l}\mathrm{N}_{2}( \pm 0.1 \%) \\
\mathrm{GTV}( \pm 25 \%) \\
D( \pm 10 \%) \\
\mathrm{P}( \pm 0.1 \mathrm{kPa})\end{array}$ & $\begin{array}{l}W( \pm 20 \%) \\
V( \pm 20 \%)\end{array}$ \\
\hline Reach ${ }^{15} \mathrm{~N}_{2}{ }^{\mathrm{d}}$ & 154 & 25 & $120-261$ & $30-65$ & $\begin{array}{l}{ }^{15} \mathrm{~N}_{2}( \pm 5 \%) \\
\text { GTV }( \pm 25 \%)\end{array}$ & $\begin{array}{l}D( \pm 10 \%) \\
W( \pm 20 \%) \\
V( \pm 10 \%)\end{array}$ \\
\hline \multicolumn{7}{|l|}{ Local in situ } \\
\hline Hyporheic ${ }^{15} \mathrm{~N}_{2}{ }^{\mathrm{d}}$ & 212 & 30 & $62-442$ & $19-133$ & $\begin{array}{l}{ }^{15} \mathrm{~N}_{2}( \pm 5 \%) \\
\text { Subsurface } \mathrm{V}( \pm 15 \%) \\
\text { Ground-water } \\
\quad \text { mixing }( \pm 25 \%)\end{array}$ & \\
\hline Chamber ${ }^{15} \mathrm{~N}_{2}{ }^{\mathrm{d}}$ & 117 & 15 & $34-213$ & $5-32$ & $\begin{array}{l}{ }^{15} \mathrm{~N}_{2}( \pm 5 \%) \\
\text { Time-series fits }\end{array}$ & \\
\hline \multicolumn{7}{|l|}{ Laboratory } \\
\hline Core $\mathrm{N}_{2}$ & 224 & 24 & $0-3,940$ & $50-140$ & $\mathrm{~N}_{2}$ blanks & \\
\hline Core ${ }^{15} \mathrm{~N}_{2}{ }^{\mathrm{d}}$ & 147 & 5 & $25-749$ & $8-84$ & ${ }^{15} \mathrm{~N}_{2}( \pm 8 U$ or $\pm 5 \%)$ & \\
\hline
\end{tabular}

Rates based on $\mathrm{N}_{2}$ or ${ }^{15} \mathrm{~N}_{2}$ production are $U_{\text {denit }}$, whereas rates based on reach $\mathrm{NO}_{3}{ }^{-}$are $U_{\mathrm{NO} \text {, net }}$

${ }^{\text {a }}$ Median of fractional uncertainty values (expressed as $\pm \%$ of $U$ ) assigned to all $U$ measurements for a given method

b Range of uncertainty values (expressed as $\pm U$ in $\mu \mathrm{mol} \mathrm{m} \mathrm{m}^{-2} \mathrm{~h}^{-1}$ ) assigned to all $U$ measurements for a given method

c $\mathrm{P}$ is atmospheric pressure. GTV is gas transfer velocity. $D, W$, and $V$ are mean stream depth, width, and tracer velocity of the reach, respectively. $U$ values were derived from small-scale methods without reference to specific reach-scale properties

d September (low flow) data only

Lagrangian sampling times. Relative downstream changes in $\mathrm{NO}_{3}{ }^{-}$concentrations were largest in September 1999, when streamflows and $\mathrm{NO}_{3}{ }^{-}$concentrations were relatively low. At that time, $\mathrm{NO}_{3}{ }^{-}$ concentrations ranged from 28 to $55 \mu \mathrm{mol} \mathrm{L}^{-1}$, decreased systematically downstream by about $35-$ $50 \%$ over $7-16 \mathrm{~km} \quad\left(0.5-2.7 \mu \mathrm{mol} \mathrm{L} \mathrm{L}^{-1} \mathrm{~h}^{-1}\right)$, and yielded $U_{\text {NO3T,net }}$ values of $170-248 \mu \mathrm{mol} \mathrm{m}^{-2} \mathrm{~h}^{-1}$ in Sugar Creek and $263 \mu \mathrm{mol} \mathrm{m}{ }^{-2} \mathrm{~h}^{-1}$ in Iroquois River.

\section{Reach $\mathrm{N}_{2}$}

Reach-scale estimates of denitrification based on ambient $\mathrm{N}_{2}$ gas concentrations (MIMS analyses) were obtained from relatively deep reaches $(>20 \mathrm{~cm})$ in both streams (IR1-7, SC6-10). Denitrification rates estimated by the reach $\mathrm{N}_{2}$ method were reported previously for these streams (Laursen and Seitzinger 2002). The model used in the current study, based on the same $\mathrm{N}_{2}$ measurements but incorporating changes in atmospheric pressure, resulted in lower estimates of denitrification than the published values except for Sugar Creek in September 1999. Denitrification fluxes $\left(U_{\text {denit }}\right)$ estimated from simulations of MIMS data ranged from 144 to $2,015 \mu \mathrm{mol} \mathrm{m}{ }^{-2} \mathrm{~h}^{-1}$ (Fig. 5a). $U_{\text {denit }}$ values generally were higher in Iroquois River (generally deeper and more turbid) than in Sugar Creek, and higher in both streams in May and June (higher flow and $\mathrm{NO}_{3}{ }^{-}$) than September (lower flow and $\mathrm{NO}_{3}{ }^{-}$), based on limited comparisons. Estimated uncertainties ranged from 67 to $1,746 \mu \mathrm{mol} \mathrm{m} \mathrm{m}^{-2} \mathrm{~h}^{-1}$. 
Generally, uncertainties in gas transfer velocity and depth contributed most to overall uncertainty in modeled denitrification rates. Denitrification estimates by this method in upper parts of Sugar Creek (SC1-5) were unsuccessful in part because of high airwater equilibration rates in shallow $(<20 \mathrm{~cm})$ turbulent reaches and(or) high rates of ground-water discharge containing excess $\mathrm{N}_{2}$ (data not shown).

\section{Reach ${ }^{15} N_{2}$}

Reach-scale changes in ${ }^{15} \mathrm{~N}_{2}$ during ${ }^{15} \mathrm{NO}_{3}{ }^{-}$isotope tracer experiments in upper reaches of Sugar Creek (T2001, T2003) during low-flow in September 2001 and September 2003 yielded simulated $U_{\text {denit }}$ values from 120 to $261 \mu \mathrm{mol} \mathrm{m} \mathrm{m}^{-2} \mathrm{~h}^{-1}$. Simulated total $\mathrm{NO}_{3}{ }^{-}$loss rates $\left(U_{\mathrm{NO} 3 \mathrm{~T}}\right)$ ranged from approximately 240 to $740 \mu \mathrm{mol} \mathrm{m}{ }^{-2} \mathrm{~h}^{-1}$, about $2-3$ times the denitrification rates. In 2003, $U_{\text {denit }}$ values in two segments of the tracer reach were correlated positively with stream $\mathrm{NO}_{3}{ }^{-}$concentrations. Modeled data were collected mostly between dusk and dawn, when $\mathrm{O}_{2}$ concentrations were below air-saturation values (minimum night-time $\mathrm{O}_{2}$ concentrations were around $140 \mu \mathrm{mol} \mathrm{L}^{-1}$ ). Because of limitations on $\mathrm{NO}_{3}{ }^{-}$loads that could be enriched isotopically, reach-scale ${ }^{15} \mathrm{NO}_{3}{ }^{-}$experiments were conducted in headwater reaches with low flow $\left(\sim 20-50 \mathrm{~L} \mathrm{~s}^{-1}\right)$. In these reaches, ground-water input containing $\mathrm{NO}_{3}{ }^{-}$ had a substantial effect on $\mathrm{NO}_{3}{ }^{-}$loads, making estimates of nitrification difficult (Böhlke et al. 2004). In September 2003, the rate of addition of non-isotopically labeled $\mathrm{NO}_{3}{ }^{-}$in the stream (from nitrification plus ground-water inflow) was $0.6-0.7$ times the rate of denitrification of isotopically labeled $\mathrm{NO}_{3}{ }^{-}$.

\section{Local in situ results}

\section{Hyporheic ${ }^{15} \mathrm{~N}_{2}$}

In situ subsurface measurements of denitrification along hyporheic-zone flow paths during ${ }^{15} \mathrm{NO}_{3}{ }^{-}$ tracer experiments in upper reaches of Sugar Creek (T2001, T2003) yielded variable rates reflecting local variation in hyporheic-zone sediment properties and water residence times. Cumulative rates for individual hyporheic-zone flow paths sampled beneath the stream bottom were integrated over the $15 \mathrm{~cm}$ vertical profiles including the hyporheic zone. Results for $U_{\text {denit }}$ ranged from 62 to $442 \mu \mathrm{mol} \mathrm{m}{ }^{-2} \mathrm{~h}^{-1}$, bracketing values derived from reach-scale data (Fig. 5). Hyporheic-zone denitrification fluxes were higher in September 2003, when stream $\mathrm{NO}_{3}{ }^{-}$concentration was around $170 \mu \mathrm{mol} \mathrm{L}{ }^{-1}$, than in September 2001, when $\mathrm{NO}_{3}{ }^{-}$concentration was $66 \mu \mathrm{mol} \mathrm{L}{ }^{-1}$. Typical pore-water profiles in September 2003 exhibited minor isotopic dilution of tracer ${ }^{15} \mathrm{NO}_{3}{ }^{-}$, indicating that nitrification occurred in the hyporheic zone. Integrated rates of coupled nitrification-denitrification were highly variable because of local heterogeneity, but mean estimates were approximately consistent with the reach scale data indicating an upper limit of around half the overall denitrification rate.

\section{Chamber ${ }^{15} \mathrm{~N}_{2}$}

In situ benthic chambers with ${ }^{15} \mathrm{NO}_{3}{ }^{-}$tracers in June and September 2003 at SC3 and T2003 yielded denitrification rates from 34 to $213 \mu \mathrm{mol} \mathrm{m}{ }^{-2} \mathrm{~h}^{-1}$ for ambient $\mathrm{NO}_{3}{ }^{-}$concentrations of $76-672 \mu \mathrm{mol} \mathrm{L}{ }^{-1}$, based on reaction simulations accounting for ${ }^{15} \mathrm{NO}_{3}{ }^{-}$ loss, ${ }^{15} \mathrm{NO}_{3}{ }^{-}$gain, and ${ }^{15} \mathrm{~N}_{2}$ production (Smith et al. submitted). Rates of $\mathrm{NO}_{3}{ }^{-}$loss were approximately 3-40 times the rates of denitrification, indicating additional $\mathrm{NO}_{3}{ }^{-}$loss mechanisms were important. Chambers installed over different bottom types yielded denitrification rates inversely correlated with sediment grain size. At SC3 in September 2003, increasing the chamber $\mathrm{NO}_{3}{ }^{-}$concentration by a factor of 7.6 (from 175 to $1,328 \mu \mathrm{mol} \mathrm{L}{ }^{-1}$ ) caused a factor of 4 increase in $U_{\text {denit }}$ (from 34 to $171 \mu \mathrm{mol}$ $\mathrm{m}^{-2} \mathrm{~h}^{-1}$ ) (Fig. 5b). Experiments with ${ }^{15} \mathrm{NH}_{4}{ }^{+}$indicated that nitrification was not an important $\mathrm{NO}_{3}{ }^{-}$ source in the chambers at $\mathrm{SC} 3$; the major mechanisms for $\mathrm{NH}_{4}{ }^{+}$loss were uptake and sorption (Smith et al. submitted).

\section{Laboratory results}

Core $\mathrm{N}_{2}$ and core ${ }^{15} \mathrm{~N}_{2}$

Benthic denitrification rates derived from microcosms with intact cores were highly variable as a result of variations in $\mathrm{NO}_{3}{ }^{-}$concentrations and local 
differences in sediment properties among core samples (Smith et al. 2006). $U_{\text {denit }}$ values ranged from about -100 to $3,900 \mu \mathrm{mol} \mathrm{m}{ }^{-2} \mathrm{~h}^{-1}$ for total $\mathrm{N}_{2}-\mathrm{N}$ production by MIMS (September 1999, May 2000, June 2001, September 2001) and were positively related to stream $\mathrm{NO}_{3}{ }^{-}$concentration (Fig. 5a). Rates derived from ${ }^{15} \mathrm{~N}_{2}-\mathrm{N}$ production from tracer ${ }^{15} \mathrm{NO}_{3}{ }^{-}$ by IRMS in June 2001 and September 2001 were 25-750 $\mu \mathrm{mol} \mathrm{m} \mathrm{m}^{-2} \mathrm{~h}^{-1}$. In addition to measurements at different times of year under different flow conditions with a range of seasonally varying ambient $\mathrm{NO}_{3}{ }^{-}$ concentrations, we also added $\mathrm{NO}_{3}{ }^{-}$to a representative set of microcosms in September 2001 and re-measured the rates. Similar positive correlations were observed between $U_{\text {denit }}$ and $\mathrm{NO}_{3}{ }^{-}$concentration in both the seasonal ambient $\mathrm{NO}_{3}{ }^{-}$dataset (Fig. 5a) and the $\mathrm{NO}_{3}{ }^{-}$addition experiments (Fig. 5b). Isotope tracer data from microcosms containing stream water without sediment in 2001 indicated no measurable denitrification $\left(U_{\text {denit }}=6 \pm 8 \mu \mathrm{mol} \mathrm{m}{ }^{-2} \mathrm{~h}^{-1}\right)$ in the water column, provided $\mathrm{O}_{2}$ concentration remained above about $30 \mu \mathrm{mol} \mathrm{L}-1$. Measurements in microcosms with lower water-column $\mathrm{O}_{2}$ concentrations that exhibited evidence of water-column denitrification were excluded from our compilation because measured stream $\mathrm{O}_{2}$ concentrations were always higher than $30 \mu \mathrm{mol} \mathrm{L}{ }^{-1}$. Primary production in core microcosms was relatively low and $\mathrm{O}_{2}$ concentrations generally were less than air-saturation values $\left(<250 \mu \mathrm{mol} \mathrm{L}^{-1}\right)$, more like dusk-to-dawn conditions in the streams rather than afternoon conditions. $U_{\text {denit }}$ values determined from simultaneous measurements of total $\mathrm{N}_{2}$ production (MIMS) and ${ }^{15} \mathrm{NO}_{3}{ }^{-}$transformation to ${ }^{15} \mathrm{~N}_{2}$ (IRMS) generally were in agreement and indicated coupled nitrification-denitrification was less important than denitrification of surface-water $\mathrm{NO}_{3}{ }^{-}$(Smith et al. 2006).

\section{Discussion}

Comparison of methods and sources of uncertainty

Our results provide a number of independent and complementary measures of denitrification and associated processes, but they are difficult to compare directly because of differences in the scales of observation and ranges of conditions in which different methods could be used. For example, the reach-scale (Lagrangian) $\mathrm{NO}_{3}{ }^{-}$mass balance and $\mathrm{N}_{2}$ saturationstate methods worked best in larger streams with no ground-water input, whereas reach-scale isotopic tracer studies typically were limited (by cost) to small-order reaches that had substantial ground-water input or where other methods were impractical. Stream network modeling indicates the major contributions of direct ground-water discharge and $\mathrm{NO}_{3}{ }^{-}$loads to streams typically occur in the first 3 stream orders (Alexander et al. 2007). This observation is important because the largest fractional losses per unit of travel time may occur in small gaining reaches where measurements and interpretations are complicated by ground-water inflow and changing stream characteristics. In-stream chambers were limited to depths large enough to enclose the chambers $(\sim 0.2 \mathrm{~m})$ but small enough for convenient monitoring and sampling ( $\sim 1 \mathrm{~m})$. However, they offered the opportunity to use stable isotope tracers in situations where $\mathrm{NO}_{3}{ }^{-}$ loads made in-stream tracer tests prohibitively expensive. Laboratory microcosms with intact cores represent a wide range of stream conditions and could be manipulated easily, but they were removed from the in situ environment. Hyporheic-zone profiles, benthic chambers, and core microcosms revealed important local heterogeneity but were subject to bias when scaled up to the stream as a whole if heterogeneous environments were not proportionally represented. Applying a diverse combination of methods at different scales over a range of conditions (depth, flow, and $\mathrm{NO}_{3}{ }^{-}$) did not necessarily provide many opportunities for direct comparisons, but some confidence was gained from general agreement of results from different parts of the stream network.

An important source of error in comparing results from different techniques was uncertainty in the physical characterization of the stream environment and its effects on conversion of units. For example, a critical conversion step for the reach-scale results occurred between measured quantities as functions of distance downstream $\left(x^{-1}\right)$ and derived quantities as functions of travel time $\left(\mathrm{h}^{-1}\right)$, which depended heavily on interpretation of tracer velocities estimated from a combination of stream metrics, tracers, and models. A stream-channel and storage-zone model (Runkel 1998) was used to obtain mean tracer velocities from our reach-scale tracer experiments, whereas reactions were modeled separately as 
vertical fluxes (gains and losses per unit area) in mixed water-column parcels moving downstream past a series of sample sites with the mean tracer velocities (e.g., Böhlke et al. 2004). This approach permitted spatial and temporal variation in model parameters such as temperature, gas transfer velocity, and ground-water input compositions, but did not account explicitly for longitudinal dispersion or vertical gradients in reaction rates (Runkel 2007). Additional uncertainties originated in conversions between different scales of observation. For example, conversion from reach-scale measurements such as longitudinal in-stream fluxes $\left(\mu \mathrm{mol} \mathrm{h}{ }^{-1}\right)$, in-stream reaction rates $\left(\mu \mathrm{mol} \mathrm{L} \mathrm{L}^{-1} \mathrm{~h}^{-1}\right)$, and first-order rate constants $\left(\mathrm{h}^{-1}\right)$ to equivalent vertical fluxes $\left(\mu \mathrm{mol} \mathrm{m}{ }^{-2} \mathrm{~h}^{-1}\right)$ and vertical transfer velocities $\left(\mathrm{m} \mathrm{h}^{-1}\right)$ relied on reach-scale estimates of stream depth and width, which were highly variable. Conversely, small-scale vertical flux measurements from hyporheic-zone profiles, benthic chambers, or core microcosms were subject to similar sources of uncertainty when converted to reach-scale parameters. Our comparisons were based on stream surveys consisting of numerous detailed transect measurements, but uncertainties in mean depths and widths used in the reach-scale tracer models were difficult to quantify.

An important ambiguity in both mass balance and isotope tracer studies in gaining stream reaches was the source of $\mathrm{NO}_{3}{ }^{-}$added within the reach, which may include varying combinations of ground-water discharge and nitrification. Although total groundwater input could be estimated accurately from instream tracer $\mathrm{Br}^{-}$dilution, the bulk composition of the input was not precisely known. $\mathrm{NO}_{3}{ }^{-}$in the hyporheic zone was derived mainly from surface water and did not represent the composition of ground-water additions. In gaining reaches of Sugar Creek, ground water discharging upward beneath the streambed was largely denitrified (no $\mathrm{NO}_{3}{ }^{-}$or $\mathrm{O}_{2}$, but large amounts of excess $\mathrm{N}_{2}$ ), whereas lateral discharge more likely contained $\mathrm{NO}_{3}{ }^{-}$and $\mathrm{O}_{2}$ owing to more limited contact with deep aquifer denitrification zones and possibly because of nitrification in near-stream soils and seepage faces. Because of this ambiguity, it was difficult to determine in-stream nitrification rates directly from reach-scale isotope tracer experiments. Furthermore, excess $\mathrm{N}_{2}$ in ground water ascending beneath the streambed could be attributed to denitrification in the saturated zone beneath the recharge area of the watershed and was largely unrelated to processes in the stream corridor. Thus, in the absence of ${ }^{15} \mathrm{~N}$ isotope tracer, excess $\mathrm{N}_{2}$ produced by denitrification of stream $\mathrm{NO}_{3}{ }^{-}$could not be quantified reliably in the presence of aquiferproduced $\mathrm{N}_{2}$ in gaining reaches, whether measured in the stream or within the hyporheic zone.

Comparison of results

Our estimates of denitrification rates derived from $\mathrm{N}_{2}$ or ${ }^{15} \mathrm{~N}_{2}$ production by different methods generally were in agreement within a factor of 2 or 3, despite differences in the scope of processes being measured, experimental artifacts, and uncertainties of measurements and scaling parameters. Some relatively direct comparisons included hyporheic zone profiles within the upper $15 \mathrm{~cm}$ beneath the September 2001 and September 2003 tracer reaches. In September 2001, integrated hyporheic zone data yielded $U_{\text {denit }}=62-83$ $\mu \mathrm{mol} \mathrm{m} \mathrm{m}^{-2} \mathrm{~h}^{-1}$ compared to the reach-scale value of $120 \mu \mathrm{mol} \mathrm{m}{ }^{-2} \mathrm{~h}^{-1}$. In September 2003, integrated hyporheic zone data yielded $U_{\text {denit }}=182-442$ $\mu \mathrm{mol} \mathrm{m} \mathrm{m}^{-2} \mathrm{~h}^{-1}$ compared to the reach-scale value of $261 \mu \mathrm{mol} \mathrm{m}{ }^{-2} \mathrm{~h}^{-1}$. Approximate agreement between the undisturbed hyporheic-zone and reach-scale rates is consistent with the hypothesis that denitrification within the hyporheic zone was a major component of the overall denitrification detected at the reach scale (Harvey et al. 2005).

Other cross-scale comparisons were provided by benthic chambers and cores in the reach-scale ${ }^{15} \mathrm{NO}_{3}{ }^{-}$tracer reaches. Four benthic chambers in a representative location within the lower part of the September 2003 tracer reach yielded composite values of $U_{\text {denit }}=213 \mu \mathrm{mol} \mathrm{m}{ }^{-2} \mathrm{~h}^{-1}$ and $U_{\text {NO3T }}=$ $532 \mu \mathrm{mol} \mathrm{m}{ }^{-2} \mathrm{~h}^{-1}$, similar to the reach ${ }^{15} \mathrm{~N}_{2}$ values of 154 and $486 \mu \mathrm{mol} \mathrm{m}{ }^{-2} \mathrm{~h}^{-1}$, respectively. Cores from the September 2001 tracer reach yielded mean $U_{\text {denit }}$ values of $217 \pm 154 \mu \mathrm{mol} \mathrm{m}{ }^{-2} \mathrm{~h}^{-1}$ from ${ }^{15} \mathrm{~N}_{2}$ data and $276 \pm 171 \mu \mathrm{mol} \mathrm{m}{ }^{-2} \mathrm{~h}^{-1}$ from $\mathrm{N}_{2}$ data, compared to $120 \mu \mathrm{mol} \mathrm{m}{ }^{-2} \mathrm{~h}^{-1}$ from the reach-scale tracer data. In a less direct comparison, chamber ${ }^{15} \mathrm{~N}_{2}$ results at SC3 yielded $U_{\text {denit }}$ values in June and September $2003\left(97 \pm 53 \mu \mathrm{mol} \mathrm{m} \mathrm{m}^{-2} \mathrm{~h}^{-1}\right)$ similar to those of nearby core $\mathrm{N}_{2}$ results in September $1999\left(96 \pm 60 \mu \mathrm{mol} \mathrm{m}{ }^{-2} \mathrm{~h}^{-1}\right)$, core $\mathrm{N}_{2}$ results in September $2001\left(172 \pm 76 \mu \mathrm{mol} \mathrm{m}^{-2} \mathrm{~h}^{-1}\right)$, and core 
${ }^{15} \mathrm{~N}_{2}$ results from September $2001 \quad(145 \pm 81$ $\mu \mathrm{mol} \mathrm{m}{ }^{-2} \mathrm{~h}^{-1}$ ). Core $\mathrm{N}_{2}$ results in May 2000 were significantly higher $\left(864 \pm 852 \mu \mathrm{mol} \mathrm{m}^{-2} \mathrm{~h}^{-1}\right.$, minus a few high values associated with plant beds).

Differences between reach-scale and small-scale measurements could have been caused in part by artifacts related to ground-water flow, dissolved gas behavior in enclosures, and biased representation of the integrated effects of benthic heterogeneity by local-scale methods. Enclosures (benthic chambers and core microcosms) may have altered solute transport and residence time distributions in reactive benthic sediments. Hyporheic flow, important for delivering surface-water $\mathrm{NO}_{3}{ }^{-}$to subsurface reaction sites, also delivered $\mathrm{O}_{2}$, which may have inhibited denitrification. Therefore, enclosures could have had either higher or lower area-weighted denitrification rates than open systems. Enclosures could have had lower rates if delivery of $\mathrm{NO}_{3}{ }^{-}$to subsurface reaction sites was limiting denitrification. Conversely, higher rates may have resulted if $\mathrm{O}_{2}$ inhibition was limiting denitrification and enclosures permitted anoxic conditions at shallower depths below the sediment-water interface, especially if the supply of electron donors was concentrated in shallower parts of the hyporheic zone.

At the reach scale, Lagrangian $\mathrm{NO}_{3}{ }^{-}$mass balance and $\mathrm{N}_{2}+\mathrm{Ar}$ measurements commonly were not sensitive enough to detect rates of denitrification that were measureable by other techniques. Lack of sensitivity in the reach $\mathrm{N}_{2}$ approach was related in part to high fluxes of excess $\mathrm{N}_{2}$ from ground-water discharge or rapid airwater gas exchange in shallow, turbulent reaches and windy conditions. For the reach $\mathrm{NO}_{3}{ }^{-}$approach, small uncertainties in measured $\mathrm{NO}_{3}{ }^{-}$concentrations caused large uncertainties in $U_{\text {denit }}$ at high flow (high $\mathrm{NO}_{3}{ }^{-}$) when benthic reactions had relatively small effects on stream $\mathrm{NO}_{3}{ }^{-}$concentrations, whereas this method was more sensitive at low flow (low $\mathrm{NO}_{3}{ }^{-}$). Net changes in $\mathrm{NO}_{3}{ }^{-}$concentrations and loads could not be attributed exclusively to denitrification, but they were included for comparison of magnitude and sensitivity. At low flow in September 1999, when $U_{\text {NO3T,net }}=170-248 \mu \mathrm{mol} \mathrm{m}{ }^{-2} \mathrm{~h}^{-1}$ in Sugar Creek and $263 \mu \mathrm{mol} \mathrm{m} \mathrm{m}^{-2} \mathrm{~h}^{-1}$ in Iroquois River, the reach $\mathrm{N}_{2}$ method gave $U_{\text {denit }}=144$ in Sugar Creek and 397 in Iroquois River, and core $\mathrm{N}_{2}$ data gave $U_{\text {denit }}=$ $76 \pm 78$ in Sugar Creek and $100 \pm 67$ in Iroquois River. Situations with $U_{\text {NO3T }}>U_{\text {denit }}$ presumably could indicate $\mathrm{NO}_{3}{ }^{-}$assimilation, whereas higher values of $U_{\text {denit }}$ would require substantial $\mathrm{NO}_{3}{ }^{-}$ sources in addition to ground-water discharge; however, processes affecting $\mathrm{NO}_{3}{ }^{-}$were not fully resolvable in the absence of isotope tracers. Mean $U_{\text {denit }}$ values from the reach $\mathrm{N}_{2}$ method generally were about equal to or higher than other denitrification results. For the limited cases where relatively direct comparisons were possible (September 1999 and May 2000), reach $\mathrm{N}_{2}$ values were similar to mean core $\mathrm{N}_{2}$ values in Sugar Creek and approximately 2-4 times the mean core $\mathrm{N}_{2}$ values in Iroquois River. Relatively high reach $\mathrm{N}_{2}$ values in Iroquois River could indicate a component of water-column denitrification in the more turbid, deeper stream if suspended organic matter was not adequately represented in the stream water used in the core microcosms; however, additional experiments would be needed to confirm these differences.

A subset of core microcosms and in situ benthic chambers included $\mathrm{NO}_{3}{ }^{-}$additions. In both cases, when ambient $\mathrm{NO}_{3}{ }^{-}$concentrations were seasonally low, $\mathrm{NO}_{3}{ }^{-}$was added to bring concentrations up to near seasonally high concentrations. The $\mathrm{NO}_{3}{ }^{-}$ addition experiments were not expected to reproduce seasonal variations in electron donors, microbial populations, and processes, which may be complex. Nevertheless, denitrification rates increased similarly with $\mathrm{NO}_{3}{ }^{-}$concentration when evaluated by two different approaches: (1) when samples were collected during low ambient $\mathrm{NO}_{3}{ }^{-}$periods (September) and high ambient $\mathrm{NO}_{3}{ }^{-}$periods (May), and (2) when $\mathrm{NO}_{3}{ }^{-}$was added during low ambient $\mathrm{NO}_{3}{ }^{-}$periods (September) (Fig. 5a, b).

\section{Reach-scale controls on benthic denitrification}

Benthic denitrification rates depend on many variables including the concentration and reactivity of organic matter in bottom sediments, the extent and rate of hyporheic flow, temperature, and the concentrations of $\mathrm{NO}_{3}{ }^{-}$and $\mathrm{O}_{2}$ in the stream and sediment pore waters. Functional forms and parameterizations of these controlling factors are incompletely known and likely complex (e.g., Garcia-Ruiz et al. 1998a; Pina-Ochoa and Alvarez-Cobelas 2006). Nevertheless, our multi-scale approach produced important lines of evidence about $\mathrm{N}$ sources and process controls at the ecosystem level: 
Denitrification occurred mainly in benthic sediments and not in the water column. In support of this, we found: (1) integrated rates of pore-water denitrification derived from ${ }^{15} \mathrm{~N}$ tracer profiles within the hyporheic zone were similar to the reach-scale rates derived from measurements in the stream (Harvey et al. 2005); and (2) sediment-free controls (unfiltered stream water) accompanying core microcosms yielded mean denitrification rates indistinguishable from zero when measured as total $\mathrm{N}_{2}$ by MIMS $\left( \pm 50-140 \mu \mathrm{mol} \mathrm{m}{ }^{-2} \mathrm{~h}^{-1}\right)$ or as ${ }^{15} \mathrm{~N}_{2}$ by IRMS ( $\pm 8 \mu \mathrm{mol} \mathrm{m} \mathrm{m}^{-2} \mathrm{~h}^{-1}, 2001$ only) when $\mathrm{O}_{2}$ concentrations remained above $30 \mu \mathrm{mol} \mathrm{L}{ }^{-1}$ (Smith et al. 2006). Bulk $\mathrm{O}_{2}$ concentrations in the water column were $\geq 100 \mu \mathrm{mol} \mathrm{L}{ }^{-1}$ during all of the field sampling and $\geq 30 \mu \mathrm{mol} \mathrm{L}{ }^{-1}$ in the core microcosms.

Denitrification was supported primarily by surface-water $\mathrm{NO}_{3}{ }^{-}$and limited to a lesser extent by nitrification as an in situ $\mathrm{NO}_{3}{ }^{-}$source. Supporting evidence includes: (1) rates of total $\mathrm{N}_{2}$ production were similar to rates of ${ }^{15} \mathrm{~N}_{2}$ production in core microcosms with ${ }^{15} \mathrm{NO}_{3}{ }^{-}$tracer (Smith et al. 2006); (2) rates of ${ }^{15} \mathrm{~N}_{2}$ production from ${ }^{15} \mathrm{NH}_{4}{ }^{+}$were low compared to rates of ${ }^{15} \mathrm{~N}_{2}$ production from ${ }^{15} \mathrm{NO}_{3}{ }^{-}$in benthic chambers (Smith et al. submitted); (3) rates of ${ }^{15} \mathrm{NO}_{3}{ }^{-}$dilution were smaller than rates of ${ }^{15} \mathrm{~N}_{2}-\mathrm{N}$ production in the 2003 reach-scale tracer experiment, placing a relatively low upper limit on the combined contribution of $\mathrm{NO}_{3}{ }^{-}$from both nitrification and lateral ground-water discharge; and (4) rates of ${ }^{15} \mathrm{NO}_{3}{ }^{-}$dilution were smaller than rates of ${ }^{15} \mathrm{~N}_{2}-\mathrm{N}$ production in hyporheic-zone profiles during the 2003 tracer test, indicating nitrification occurred, but was not the major source of $\mathrm{NO}_{3}{ }^{-}$in the sediment pore fluid. Observations (1), (2), and (3) are based on surface-water measurements that could have missed tightly coupled nitrification-denitrification within the subsurface, and it is possible the enclosure methods (1 and 2) altered nitrification rates by altering hyporheic flow. Observation (4) indicates that subsurface nitrification was at least a minor source of $\mathrm{NO}_{3}{ }^{-}$within the hyporheic zone itself, and isotopic analyses of $\mathrm{NO}_{2}{ }^{-}$in surface water also indicated low rates of nitrification somewhere in the system (Böhlke et al. 2004; Böhlke et al. 2007). Nitrification in these streams may have contributed to maintaining baseline $\mathrm{NO}_{3}{ }^{-}$concentrations during low flow (Fig. 3), but even then it is likely that some $\mathrm{NO}_{3}{ }^{-}$was from shallow ground-water discharge, possibly augmented by nitrification in seepage faces in the incised stream banks. Documented nitrification-limited denitrification is more common in estuarine or marine systems (Jenkins and Kemp 1984; Kana et al. 1998; Cornwell et al. 1999), which commonly have lower $\mathrm{NO}_{3}{ }^{-}$ concentrations, higher sediment $\mathrm{NH}_{4}^{+}$concentrations, and steeper sub-bottom redox gradients (more likely controlled by diffusion than by advection) than the high- $\mathrm{NO}_{3}{ }^{-}$streams described here.

Denitrification rates were directly correlated with stream $\mathrm{NO}_{3}{ }^{-}$concentrations. Evidence includes: (1) seasonal variations in $\mathrm{N}_{2}$ gas-production estimates from reach-scale measurements of $\mathrm{N}_{2}$ saturation states; (2) decreasing simulated denitrification rate for the September 2003 in-stream ${ }^{15} \mathrm{~N}$ tracer test through a $3-\mathrm{km}$ reach with decreasing $\mathrm{NO}_{3}{ }^{-}$concentration; (3) correlation between stream $\mathrm{NO}_{3}{ }^{-}$ concentrations and integrated $\mathrm{N}_{2}$ production rates within the hyporheic zone during ${ }^{15} \mathrm{NO}_{3}{ }^{-}$tracer tests; (4) increase in $\mathrm{N}_{2}$ production rate after addition of $\mathrm{NO}_{3}{ }^{-}$to core microcosms and a benthic chamber; and (5) seasonal differences in mean $\mathrm{N}_{2}$ gas production rates in core microcosms. These results are consistent with the hypothesis that benthic denitrification was limited, at least in part, by transport of $\mathrm{NO}_{3}{ }^{-}$into streambed sediments.

\section{Relation between denitrification and $\mathrm{NO}_{3}{ }^{-}$ concentration}

Although benthic denitrification rates $\left(U_{\text {denit }}\right)$ were related to $\mathrm{NO}_{3}{ }^{-}$concentrations, the increase in $U_{\text {denit }}$ was not proportional to the increase in concentration and the overall response was less than first-order. The relation between $U_{\text {denit }}$ and $\mathrm{NO}_{3}{ }^{-}$had large uncertainties, and it could be represented by several different functions (Fig. 5a). One function that fit the data reasonably well is a form of saturation equation (similar to the Michaelis-Menten equation):

$U_{\text {denit }}=\left[\mathrm{NO}_{3}^{-} * U_{\max }\right] /\left[\mathrm{NO}_{3}^{-}+K_{\mathrm{s}}\right]$,

where $U_{\text {denit }}$ is denitrification rate expressed as a vertical flux per unit area $\left(\mu \mathrm{mol} \mathrm{m} \mathrm{m}^{-2} \mathrm{~h}^{-1}\right), \mathrm{NO}_{3}{ }^{-}$is stream $\mathrm{NO}_{3}^{-}$concentration $\left(\mu \mathrm{mol} \mathrm{L}{ }^{-1}\right), \quad U_{\text {max }}$ $\left(\mu \mathrm{mol} \mathrm{m}{ }^{-2} \mathrm{~h}^{-1}\right)$ is the maximum value of $U_{\text {denit }}$ obtainable at high $\mathrm{NO}_{3}{ }^{-}$concentration, and $K_{\mathrm{s}}$ $\left(\mu \mathrm{mol} \mathrm{L}{ }^{-1}\right)$ is the $\mathrm{NO}_{3}{ }^{-}$concentration at which $U_{\text {denit }}=0.5 \cdot U_{\max }$. Multiple error minimization 
calculations with Microsoft Excel Solver yielded the following parameters for the complete set of unweighted data: $U_{\max }=640 \mu \mathrm{mol} \mathrm{m} \mathrm{m}^{-2} \mathrm{~h}^{-1}$ and $K_{\mathrm{s}}=180 \mu \mathrm{mol} \mathrm{L}^{-1}$ (Fig. 5a). When different types of measurements were weighted somewhat arbitrarily with approximately equal contributions from laboratory data and in situ data and some preference for ${ }^{15} \mathrm{~N}_{2}$ data (each value weighted 10,50,10,10, 1, and 2 times for reach $\mathrm{N}_{2}$, reach ${ }^{15} \mathrm{~N}_{2}$, hyporheic ${ }^{15} \mathrm{~N}_{2}$, chamber ${ }^{15} \mathrm{~N}_{2}$, core $\mathrm{N}_{2}$, and core ${ }^{15} \mathrm{~N}_{2}$, respectively), Solver fits yielded $U_{\max }=700 \mu \mathrm{mol} \mathrm{m} \mathrm{m}^{-2} \mathrm{~h}^{-1}$ and $K_{\mathrm{s}}=320 \mu \mathrm{mol} \mathrm{L}^{-1}$ (Fig. 5a). Although the saturation equation is used commonly to describe enzymatic limitation on reaction rates in homogeneous systems, and it has been used to describe nutrient uptake rates in streams (Garcia-Ruiz et al. 1998b; Payn et al. 2005; Opdyke and David 2007; Herrman et al. 2008), there is not necessarily a direct link between these different applications, and a mechanistic model for this relation may be complex for systems with benthic gradients and(or) hyporheic flow.

Our data also were described approximately with a simple power law equation:

$U_{\text {denit }}=a *\left[\mathrm{NO}_{3}^{-}\right]^{b}$,

where $a$ and $b$ are fit parameters and $U_{\text {denit }}$ and $\mathrm{NO}_{3}{ }^{-}$ have units of $\mu \mathrm{mol} \mathrm{m}{ }^{-2} \mathrm{~h}^{-1}$ and $\mu \mathrm{mol} \mathrm{L}^{-1}$, respectively. Analogous relations have been proposed, for example, between $U_{\mathrm{NO} 3 \mathrm{~T}}$ and $\mathrm{NO}_{3}{ }^{-}$(O'Brien et al. 2007), and between $v_{\mathrm{f} \text {,denit }}$ and $\mathrm{NO}_{3}{ }^{-}$(Mulholland et al. 2008) based on multi-site comparisons of reachscale measurements. Our aggregated data yielded $U_{\text {denit }}=26 *\left[\mathrm{NO}_{3}{ }^{-}\right]^{0.44}$ (unweighted) and $U_{\text {denit }}=$ $14 *\left[\mathrm{NO}_{3}{ }^{-}\right]^{0.54}$ (weighted) (Fig. 5a). The mean differences between measured and modeled $U_{\text {denit }}$ values were $243 \pm 1 \mu \mathrm{mol} \mathrm{m} \mathrm{m}^{-2} \mathrm{~h}^{-1}$ for both Eqs. 1 and 2 (unweighted), and therefore inconclusive with respect to which equation gave a better description of the data.

One difference between Eqs. 1 and 2 is that Eq. 2 predicted higher values of $U_{\text {denit }}$ at low $\mathrm{NO}_{3}^{-}$ concentrations $\left(<50 \mu \mathrm{mol} \mathrm{L}{ }^{-1}\right)$, more like models that include coupled nitrification/denitrification. A positive relation between $U_{\text {denit }}$ and $\mathrm{NO}_{3}^{-}$derived from experiments with estuarine sediment cores was fit to a linear equation with slope of $0.0013 \mathrm{~m} \mathrm{~h}^{-1}$ and intercept at around $60 \mu \mathrm{mol} \mathrm{m} \mathrm{m}^{-2} \mathrm{~h}^{-1}$, and the intercept was interpreted as the rate of coupled nitrification-denitrification (Kana et al. 1998). Taking the same approach with our data would give a slope of about $0.0067 \mathrm{~m} \mathrm{~h}^{-1}$ and an intercept between 0 and $100 \mu \mathrm{mol} \mathrm{m} \mathrm{m}^{-2} \mathrm{~h}^{-1}$. It is difficult to rule this out based on the overall trends in Fig. 5a, given the diversity of our methods and our general lack of $U_{\text {denit }}$ data at $\mathrm{NO}_{3}^{-}$concentrations below about $20 \mu \mathrm{mol} \mathrm{L}^{-1}$, but other data (e.g. Smith et al. 2006) indicated relatively low nitrification rates.

In Fig. 5c, our data are compared with reach-scale denitrification rates measured by the LINX2 project in streams with generally lower $\mathrm{NO}_{3}{ }^{-}$concentrations (Mulholland et al. 2008). The LINX2 data were fit to a power-law function (Mulholland et al. 2008) $\left(v_{\mathrm{f} \text {,denit }}=-0.493 * \log \left[\mathrm{NO}_{3}{ }^{-}\right]-2.975\right.$, with $v_{\mathrm{f} \text {,denit }}$ in $\mathrm{cm} \mathrm{s}^{-1}$ and $\mathrm{NO}_{3}{ }^{-}$in $\mu \mathrm{g} \mathrm{N} \mathrm{L}^{-1}$, which is equivalent to $U_{\text {denit }}=10.4 *\left[\mathrm{NO}_{3}{ }^{-}\right]^{0.507}$ in our units. Combining the LINX2 data with ours, we obtained the following (Fig. 5c): for the power law equation, $U_{\text {denit }}=22 *\left[\mathrm{NO}_{3}{ }^{-}\right]^{0.47}$ (unweighted) or $U_{\text {denit }}=$ $17 *\left[\mathrm{NO}_{3}{ }^{-}\right]^{0.51}$ with weighting to equalize the total residuals from the two studies; for the saturation equation, $U_{\max }=640 \mu \mathrm{mol} \mathrm{m}{ }^{-2} \mathrm{~h}^{-1}$ and $K_{\mathrm{s}}=180$ $\mu \mathrm{mol} \mathrm{L}{ }^{-1}$ (unweighted or weighted), in each case with almost identical mean differences between measured and calculated $U_{\text {denit }}$ for the two equations. Thus, although the form of the fit was not certain, the apparent continuity of the relation between our results (smaller number of sites, multiple scales, temporal variation in $\mathrm{NO}_{3}{ }^{-}$, generally higher $\mathrm{NO}_{3}{ }^{-}$) and the LINX2 study (more sites, reach scale, spatial variation in $\mathrm{NO}_{3}{ }^{-}$, generally lower $\mathrm{NO}_{3}{ }^{-}$) is evidence for a common overall control of $U_{\text {denit }}$ by stream $\mathrm{NO}_{3}{ }^{-}$, albeit with considerable local variability.

Spatial and temporal variations of denitrification

Uncertainties in the $U_{\max }, K_{\mathrm{s}}, a$, and $b$ parameters (and the equations themselves) used to describe our aggregated dataset must be related in part to spatial and temporal variations in microbial communities and reactive substrates, as well as transport properties in and near the streambed (Voytek et al. 2001; Smith et al. 2006; Smith et al. submitted), which would need to be represented by additional variables other than $\mathrm{NO}_{3}{ }^{-}$. This is illustrated by the core microcosm 
$\mathrm{NO}_{3}{ }^{-}$addition results (Fig. 5b). There, arrows connecting $U_{\text {denit }}$ measurements before and after $\mathrm{NO}_{3}{ }^{-}$ additions are roughly parallel, indicating a relatively consistent proportional effect of $\mathrm{NO}_{3}{ }^{-}$concentration, whereas other variables acted somewhat independently, causing individual microcosms to have different values of $U_{\text {denit }}$ before and after $\mathrm{NO}_{3}{ }^{-}$ addition.

Benthic characteristics commonly related to denitrification rates include plant abundance, concentration and $\mathrm{C} / \mathrm{N}$ ratio of organic matter in near-surface sediments, and grain size and permeability of bottom sediments (e.g., Garcia-Ruiz et al. 1998a; O'Connor et al. 2006; Arango et al. 2007; Opdyke and David 2007). These characteristics vary over spatial scales ranging from centimeters to 10 's of meters in relation to local stream geomorphology and sediment transport properties. In our study, relatively high denitrification rates were obtained with cores extracted from relatively calm pools and back-bar environments, which are areas of fine sediment and organic matter deposition; whereas lower rates were obtained with cores from higherenergy stream environments (sand bars, gravel flats, and riffles), which had coarser sediments with less organic matter (Voytek et al. 2001; Smith et al. 2006). Highest rates $\left(U_{\text {denit }}>3,000 \mu \mathrm{mol} \mathrm{m}{ }^{-2} \mathrm{~h}^{-1}\right)$ were in core microcosms from aquatic plant beds with local surficial organic-rich sediment layers. Local variations also were observed in the vertical dimension within the hyporheic zone, where local sediment stratigraphy controlled flow and reaction rates as a function of depth (Harvey et al. 2005).

We also observed temporal changes in the overall stream-bottom characteristics over periods of hours to weeks in response to changing weather and streamflow. For example, a flood in June 2001 eroded many of the aquatic plants and much of the organic substrate from the stream bottom in Sugar Creek. As a result, organic-rich bottom sediments were scarce and core microcosms yielded relatively low denitrification rates $\left(U_{\text {denit }}=290 \pm 151 \mu \mathrm{mol} \mathrm{m}{ }^{-2} \mathrm{~h}^{-1}\right)$, despite having high $\mathrm{NO}_{3}{ }^{-}$concentrations $\left(\approx 1,120 \mu \mathrm{mol} \mathrm{L}^{-1}\right)$ (Smith et al. 2006) (Fig. 5a). Analogous variations in denitrification rates may occur at longer time scales in response to seasonal changes in plant growth and stream flow, or over diel time scales in response to production and consumption of $\mathrm{O}_{2}$ or labile organic matter, especially in the upper reaches of Sugar Creek
(Tobias et al. 2007). High $\mathrm{O}_{2}$ concentrations could inhibit denitrification in the presence of excess $\mathrm{NO}_{3}{ }^{-}$ or enhance coupled nitrification-denitrification where $\mathrm{NO}_{3}{ }^{-}$is limiting (Christensen et al. 1990; Rysgaard et al. 1994; O'Connor and Hondzo 2008). Changes in denitrification rates resulting directly from diel $\mathrm{O}_{2}$ cycles were not addressed in the current study. Surfacewater $\mathrm{O}_{2}$ concentrations during our measurements generally were $\geq 100 \mu \mathrm{mol} \mathrm{L}{ }^{-1}$ except in a few core microcosms with $\mathrm{O}_{2}=30-100 \mu \mathrm{mol} \mathrm{L}{ }^{-1}$ and generally were $\leq$ air saturation values (i.e., not elevated by high rates of photosynthesis) except for parts of the reach $\mathrm{NO}_{3}{ }^{-}$and reach $\mathrm{N}_{2}$ surveys.

In the context of stream networks, it is possible that spatial variations in benthic denitrification would be less in larger streams and more in smaller streams, in response to local differences in stream morphology, depth, and benthic productivity. We found some indication that $U_{\text {denit }}$ was less variable in Iroquois River than in Sugar Creek (Voytek et al. 2001). Locally, the highest rates of denitrification were in patches where benthic production and consumption of organic matter occurred daily, and where coarse sediments promoted hyporheic flow, as in shallow upper reaches of Sugar Creek. Mean denitrification rates from core microcosms were somewhat lower in Iroquois River, where benthic primary production and mean grain size were less (Voytek et al. 2001; Smith et al. 2006). These tendencies could complicate predictions of downstream watershed-scale changes in rate constants $\left(k 1_{\text {denit }}\right)$ with stream size based on relations with $\mathrm{NO}_{3}{ }^{-}$flux (depth and mass) (e.g., Alexander et al. 2000) or concentration (Mulholland et al. 2008; Alexander et al. 2008b) (this study).

Combining the effects of $\mathrm{NO}_{3}{ }^{-}$limitation in the sediment pore water with the sediment reactive substrate characteristics, we expect the fractional rate of stream $\mathrm{NO}_{3}{ }^{-}$removed by benthic denitrification $\left(k 1_{\text {denit }}\right)$ generally will be higher in summer (more primary production, fresh organic matter, low flows, shallow depths, lower $\mathrm{NO}_{3}{ }^{-}$concentrations) and lower in winter and spring. Because the bulk of watershed $\mathrm{NO}_{3}{ }^{-}$discharge occurs in winter and spring, we also expect the effect of denitrification on annual $\mathrm{NO}_{3}{ }^{-}$loads to be more like those measured during high flow than at low flow (Royer et al. 2004; Smith et al. 2006). Although we have several different lines of evidence that benthic denitrification fluxes $\left(U_{\text {denit }}\right)$ and transfer velocities $\left(v_{\mathrm{f}, \text { denit }}\right)$ 
depended on overlying water-column $\mathrm{NO}_{3}{ }^{-}$concentrations, we do not have direct evidence for the effects of seasonal temperature variations. If rates were lower at lower temperature, then the conclusion above would be magnified and almost all seasonal stream variables would conspire to permit larger fractions of $\mathrm{NO}_{3}{ }^{-}$to escape denitrification in cooler seasons (see below).

Generalized expressions of nitrogen transmission through streams

Expressions for the rate of $\mathrm{N}$ loss from a stream depend on the types of available data and the conceptual model for how losses occur. A single first-order decay constant $k 1_{\text {denit }}$ could represent $\mathrm{NO}_{3}{ }^{-}$loss from streams by benthic denitrification only if the rate of $\mathrm{NO}_{3}{ }^{-}$loss from the water column ( $r_{\text {denit }}$, in $\mu \mathrm{mol} \mathrm{L} \mathrm{L}^{-1} \mathrm{~h}^{-1}$ ) were proportional to the stream $\mathrm{NO}_{3}{ }^{-}$concentration, but this generally was not the case (Fig. 6). A common procedure in regional models allows $k 1_{\text {denit }}$ to vary with watercolumn depth to accommodate changes in total $\mathrm{NO}_{3}{ }^{-}$ mass while holding the benthic reaction rate constant. In the coordinate system of Fig. $6 \mathrm{~b}$ ( $k 1$ vs. depth), this procedure is represented by each of the smooth curves representing a set of fractional loss rates for a constant value of $v_{\mathrm{f} \text {,denit }}$ (in $\mathrm{m} \mathrm{day}^{-1}$ ) (e.g., Howarth et al. 1996). The generalized pattern of our aggregated data, as well as regional spatial regressions of loadings and exports (e.g., SPARROW, Alexander et al. 2000; Alexander et al. 2008a), are similar to those indicated by constant $v_{\mathrm{f}}$ curves, but with considerable scatter and a potential range of $v_{\mathrm{f}}$ values. Our data indicate additional parameters could improve predictions of $\mathrm{NO}_{3}{ }^{-}$losses by denitrification in streams with varying $\mathrm{NO}_{3}{ }^{-}$concentrations. For example, for a given benthic denitrification flux $\left(U_{\text {denit }}\right)$, a stream will plot higher (higher $\left.v_{\mathrm{f}}\right)$ if the concentration is low because less time is required to remove $\mathrm{NO}_{3}{ }^{-}$from a given water column. This is illustrated in Fig. 6a, where the data arrays for Iroquois River (closed symbols) and Sugar Creek (open symbols) are offset because, although they have similar annual ranges of $\mathrm{NO}_{3}{ }^{-}$concentrations, they have different $\mathrm{NO}_{3}{ }^{-}$concentrations when their depths (flows) are similar (Fig. 3). Similarly, for a given $\mathrm{NO}_{3}{ }^{-}$concentration, a stream will plot higher if the benthic denitrification flux $\left(U_{\text {denit }}\right)$ is higher.
Independent fits of the low-flow (low $\mathrm{NO}_{3}{ }^{-}$) data and high-flow (high $\mathrm{NO}_{3}{ }^{-}$) datasets in Fig. 5a, assuming $v_{\mathrm{f} \text {,denit }}$ was constant in each case, would yield $v_{\mathrm{f} \text {,denit }}$ values of 0.06 and $0.02 \mathrm{~m} \mathrm{day}^{-1}$, respectively (labeled curves in Fig. 6). Thus, our data indicate no single value of $k 1, v_{\mathrm{f}}$, or $U$ is appropriate for describing denitrification in the Iroquois River basin, where $\mathrm{NO}_{3}{ }^{-}$concentrations are related to flow temporally but not necessarily spatially (Fig. 3). Instead, in the absence of local data on sediment characteristics and hyporheic flows, and in the absence of major temperature effects, an approximation of reach-scale variations in denitrification losses of $\mathrm{NO}_{3}{ }^{-}$ in these streams could be derived indirectly from stream flow as follows: (1) estimate stream $\mathrm{NO}_{3}{ }^{-}$ concentrations from the relation between $\mathrm{NO}_{3}{ }^{-}$and flow; (2) estimate vertical denitrification fluxes $\left(U_{\text {denit }}\right)$ from the relation between $U_{\text {denit }}$ and $\mathrm{NO}_{3}{ }^{-}$; and (3) calculate $r_{\text {denit }}, v_{\mathrm{f} \text {,denit }}$, or $k 1_{\text {denit }}$ using $U_{\text {denit }}, \mathrm{NO}_{3}{ }^{-}$, and stream depth (which may be estimated from flow).

Hypothetical models of temporal variations in denitrification

To illustrate general features of our data and interpretations, and highlight relations among different denitrification rate expressions, we constructed hypothetical models of temporal variations in $\mathrm{NO}_{3}{ }^{-}$ concentrations, loads, and denitrification rates in Sugar Creek at SC3 and Iroquois River at IR1 at seasonal and event-related time scales (Figs. 7, 8, and 9). Calculations of generalized seasonal variations began with smoothed long-term mean stream flows representing sites IR1 and $\mathrm{SC} 3$ (Fig. 7). $\mathrm{NO}_{3}^{-}$ concentrations were derived from flows by using logarithmic relations derived from Fig. 3, then vertical denitrification fluxes $\left(U_{\text {denit }}\right)$ were derived from the $\mathrm{NO}_{3}^{-}$concentrations by using the saturation equation (Eq. 1) with unweighted parameters derived from Fig. 5a. Those results were recalculated in terms of vertical denitrification transfer velocities $\left(v_{\mathrm{f}, \mathrm{denit}}\right)$ and fractional denitrification rate constants $\left(k 1_{\text {denit }}\right)$. Stream depths were calculated from flows by using a general empirical relation (Leopold and Maddock 1953).

With $\mathrm{NO}_{3}^{-}$concentration as the primary control of $U_{\text {denit }}$, there was a strong seasonal variation and positive correlation between flow, $\mathrm{NO}_{3}^{-}$, and $U_{\text {denit }}$ (Fig. 7a-c). However, because $U_{\text {denit }}$ was not fully 
Fig. 7 Hypothetical seasonal variations in stream parameters and denitrification rates at representative sites in Iroquois River (IR1) and Sugar Creek (SC3). a Smoothed values of stream flow and temperature; flows at IR1 were calculated as 31-day moving mean values of the median daily flows at the Foresman, Indiana stream gage from 1948 to 2003 (USGS 2008); flows at SC3 were assumed to be 0.08 times the Foresman values, based on a comparison of biweekly measurements at IR1 and SC3 from 2000 to 2002 (Fig. 2) (Antweiler et al. 2005b); temperatures are 31-day moving mean values of the combined biweekly measurements at IR1 and SC3, which were essentially the same. b Estimated daily $\mathrm{NO}_{3}{ }^{-}$concentrations based on biweekly data from 2000 to 2002 at IR1 $\left(\mathrm{NO}_{3}{ }^{-}=575 * \log Q\right)$ and $\mathrm{SC} 3\left(\mathrm{NO}_{3}{ }^{-}=\right.$ $680 * \log Q+750)$; in both streams, the minimum concentration at low flow was held at $40 \mu \mathrm{mol} \mathrm{L}{ }^{-1}$ (Fig. 3). c Estimated values of $U_{\text {denit }}$ calculated from an unweighted fit of our data to Eq. 1 (Fig. 5a), with $U_{\max }=640 \mu \mathrm{mol} \mathrm{m}{ }^{-2} \mathrm{~h}^{-1}$ and $K_{\mathrm{s}}=$ $180 \mu \mathrm{mol} \mathrm{L}^{-1}$ (solid curves, no temperature effect, $\mathrm{q} 10=1$ ); hypothetical effects of changing temperature (dashed curves, with q10 = 2) were superimposed on the estimated $20^{\circ} \mathrm{C} U_{\text {denit }}$ values: $U_{\text {denit,T}}=U_{\text {denit,20 }} * \mathrm{q} 10^{[(T-20) / 10]}$. d Estimated values of $v_{\mathrm{f} \text {,denit }}$ calculated from $U_{\mathrm{denit}} / \mathrm{NO}_{3}{ }^{-}$. e Estimated values of $k 1_{\text {denit }}$ calculated from $v_{\mathrm{f} \text {,denit }} /$ depth; depth was calculated from $Q$ using the empirical relation (Leopold and Maddock 1953): $\operatorname{depth}(\mathrm{m})=0.2612 * Q\left(\mathrm{~m}^{3} \mathrm{~s}^{-1}\right)^{0.3966}$

proportional to $\mathrm{NO}_{3}^{-}$concentration, the denitrification velocity $\left(v_{\mathrm{f}, \text { denit }}\right)$ also exhibited seasonal variations, with relatively high values in summer and fall. As a result, the streams traced annual cycles that cross lines of equal $v_{\mathrm{f} \text {,denit }}$ in a plot of $k 1_{\text {denit }}$ versus stream depth (or flow) (Fig. 9). Iroquois River and Sugar Creek followed different seasonal cycles that were displaced horizontally in Fig. 9 (see also Fig. 6a) because they had different flows but similar annual ranges of $\mathrm{NO}_{3}{ }^{-}$concentration (Fig. 3) and because $U_{\text {denit }}$ was modeled as a non-linear function of $\mathrm{NO}_{3}^{-}$ (Fig. 5a). Similarly, two streams with similar ranges of flow but different $\mathrm{NO}_{3}^{-}$concentrations would follow different cycles that would be displaced vertically. With $\mathrm{NO}_{3}^{-}$as a function of flow and with $\mathrm{NO}_{3}^{-}$as the only control of denitrification rates, seasonal variations in Fig. 9 were reversible (single curve for each stream).

Although our measurements did not address temperature effects on denitrification, some potential effects of seasonal temperature variations are illustrated for comparison in Figs. 7 and 9. Temperature effects on denitrification rates have been documented in the laboratory but are difficult to resolve from effects of other variables in the field (Pfenning and McMahon 1996; Royer et al. 2004; Pina-Ochoa and
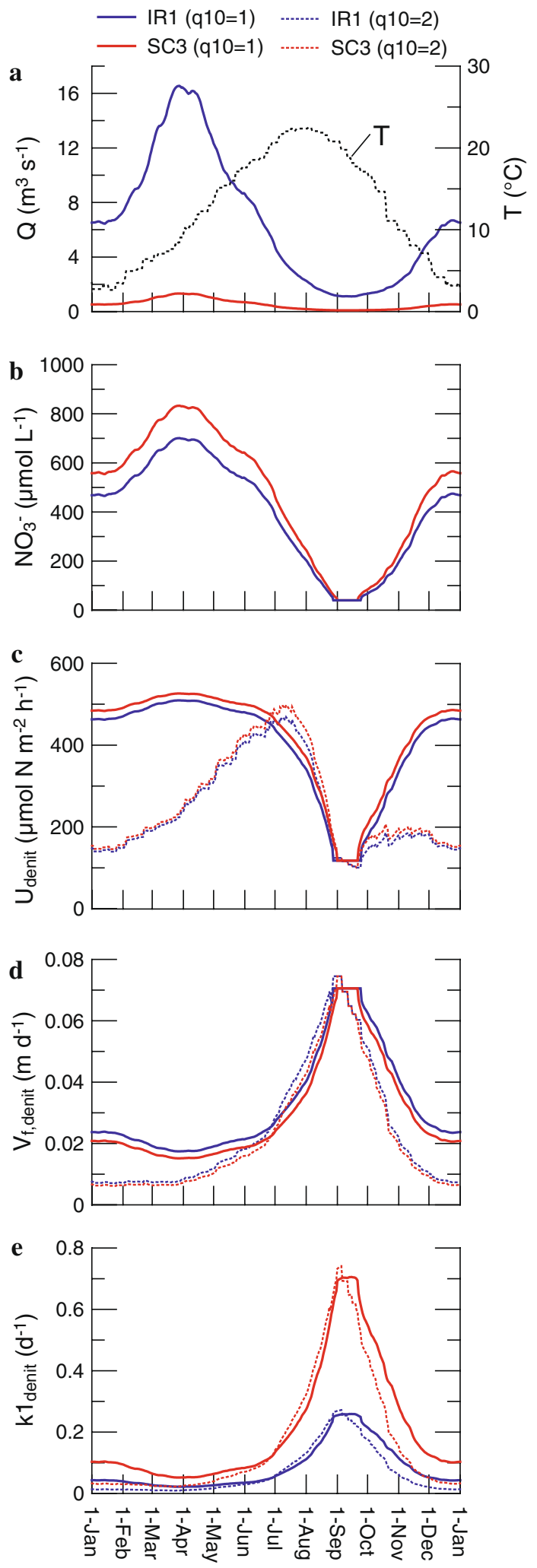
Fig. 8 Hypothetical variations in denitrification rates before, during, and after a high-flow event in Sugar Creek. Flow and $\mathrm{NO}_{3}{ }^{-}$concentration data are from the Milford, Illinois stream gage in May 1990 (USGS 2008), smoothed slightly to highlight major patterns. Denitrification rates were calculated as in Fig. $7\left(U_{\text {denit }}\right.$ as a function of $\mathrm{NO}_{3}{ }^{-}$, saturation equation, unweighted, shown as solid curves), and with the additional assumption that the supply of reactive substrates was reduced by one half during the rising limb of the hydrograph and remained low subsequently ("flushed", shown as dashed curves)

Alvarez-Cobelas 2006; Opdyke and David 2007; Herrman et al. 2008). Temperature effects include changes in microbial community structure and biomass, as well as thermal effects on enzymatic processes, resulting in complex functions with effective q10 values ranging from around 1 (no temperature effect) to 2 (doubling the rate for $10^{\circ} \mathrm{C}$ increase in $T$ ) or more (e.g., Herbert and Nedwell 1990), where q10 is defined by: rate $_{T} /$ rate $_{20}=$ $\mathrm{q} 10^{[(T-20) / 10]}$, with $T, 10$, and 20 in ${ }^{\circ} \mathrm{C}$. Hypothetical curves in Figs. 7 and 9 illustrate the effects of varying q10 from 1 to 2 , superimposed on the constanttemperature effects of $\mathrm{NO}_{3}{ }^{-}$concentration. Because changes in temperature and $\mathrm{NO}_{3}{ }^{-}$concentration were not in phase (Fig. 7a), denitrification rates for $\mathrm{q} 10=2$ exhibited seasonal variations that were not directly related to either $\mathrm{NO}_{3}{ }^{-}$or temperature. $U_{\text {denit }}$ peaked in mid-summer at about the same time when temperature peaked because the stream $\mathrm{NO}_{3}{ }^{-}$concentration also was high. $U_{\text {denit }}$ decreased rapidly in late summer and fall because of decreasing $\mathrm{NO}_{3}{ }^{-}$ concentration, then remained low through winter because of low temperature. Because stream temperatures were not correlated exactly with stream flow or $\mathrm{NO}_{3}{ }^{-}$concentration, any simple function relating denitrification with temperature introduced hysteresis in the relation between $U_{\text {denit }}$ and $\mathrm{NO}_{3}{ }^{-}$or between $k 1_{\text {denit }}$ and stream depth (Fig. 9).

In addition to seasonal variations, large portions of the stream-flow records correspond to short-term high-flow events (Fig. 2). High-flow events are important times for $\mathrm{NO}_{3}{ }^{-}$transport, and they may alter the properties of the system in ways that affect benthic denitrification. Relations between $\mathrm{NO}_{3}{ }^{-}$ concentrations, loads, and denitrification rates at the event time scale are even less well documented than seasonal variations, but some of our observations and speculations are summarized in Figs. 8 and 9.
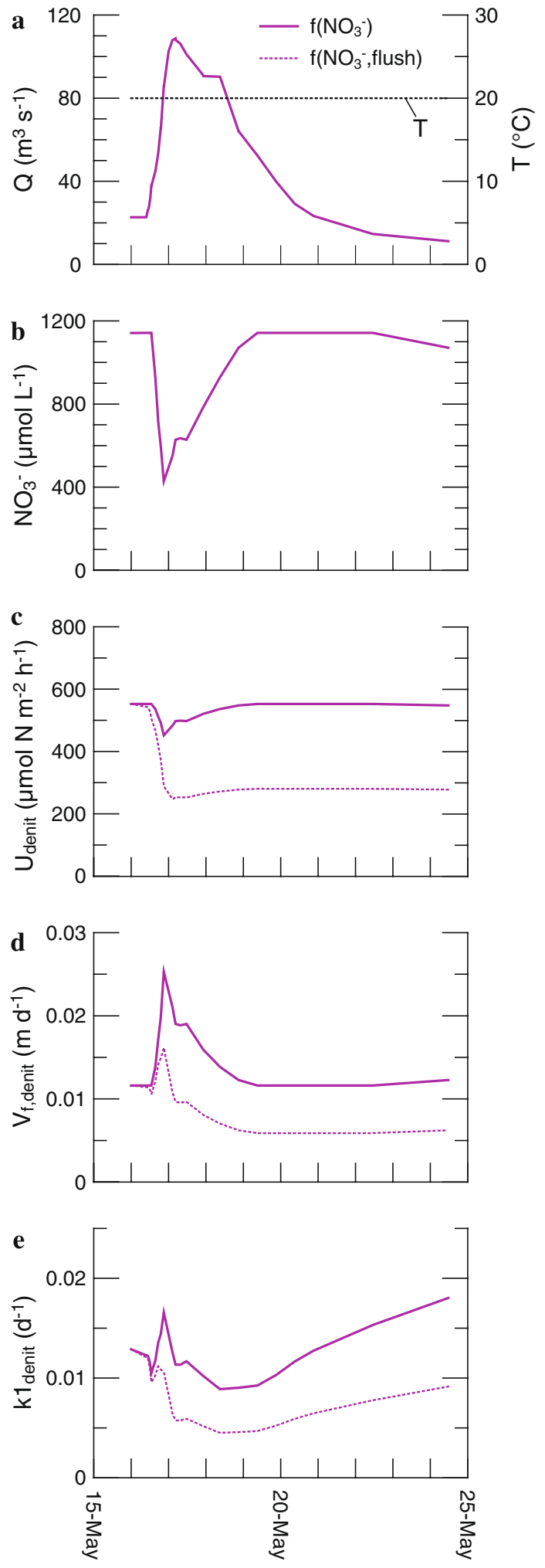

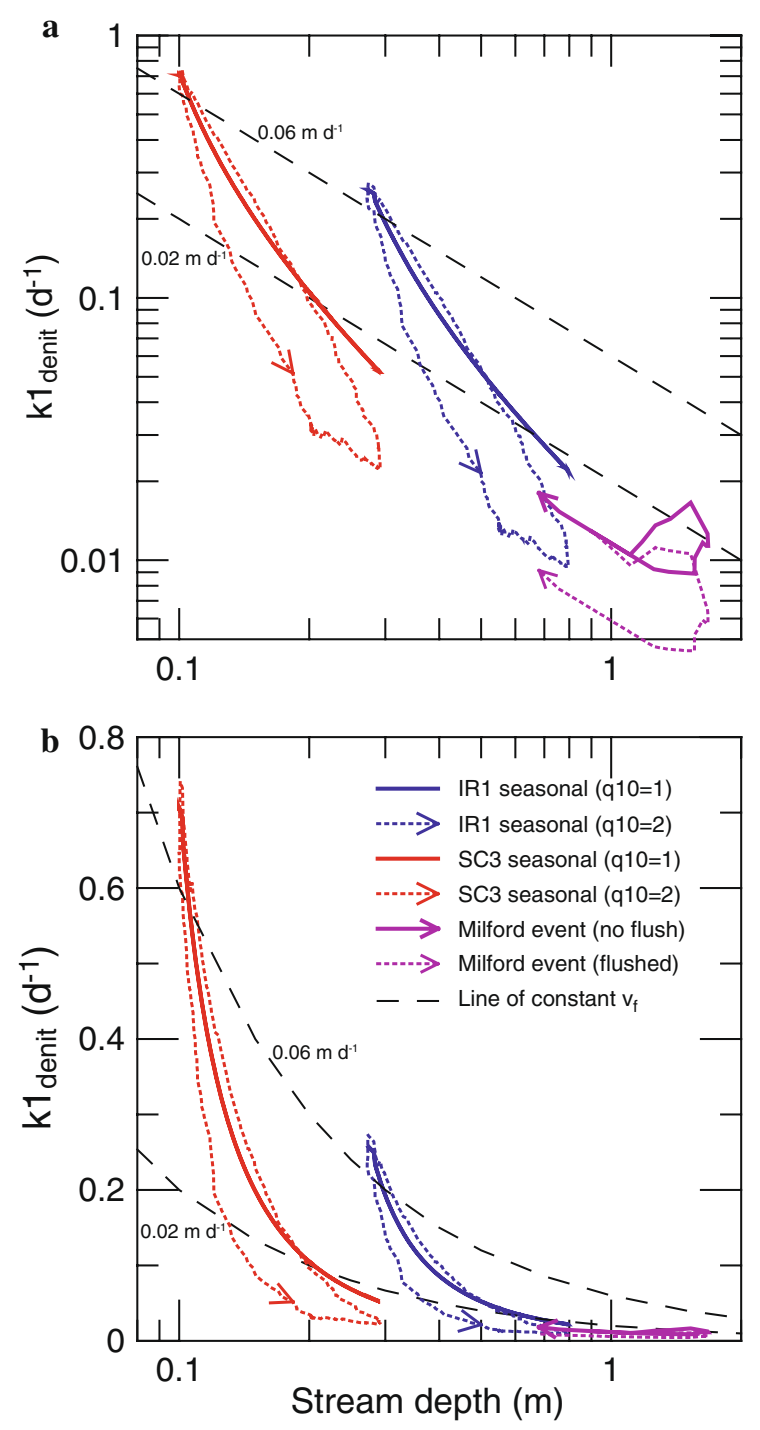

Fig. 9 Hypothetical temporal variations in $k 1_{\text {denit }}$ versus stream depth, illustrating offsets and hysteresis effects for different streams and different event scenarios. Values of $k 1_{\text {denit }}$ are from Fig. 7 (seasonal time scale, IR1 and SC3) and Fig. 8 (event time scale, Sugar Creek at Milford). Lines of constant $v_{\mathrm{f} \text {,denit }}$ at 0.02 and $0.06 \mathrm{~m} \mathrm{day}^{-1}$ are shown for reference (see Fig. 6). Arrows indicate the direction of time in curves with hysteresis (arrow heads are plotted at December 1 in the seasonal curves with $\mathrm{q} 10=2$ ). Seasonal curves with $\mathrm{q} 10=1$ are reversible (no hysteresis) in this model. a Log plot, similar to Fig. 6a. b Log-linear plot, similar to Fig. 6 b

Combining results from core microcosms, benthic chambers, and reach-scale ${ }^{15} \mathrm{NO}_{3}{ }^{-}$tracers, it appears the rate of total $\mathrm{NO}_{3}{ }^{-}$loss $\left(U_{\mathrm{NO} 3 \mathrm{~T}}\right)$ was greater than the rate of denitrification $\left(U_{\text {denit }}\right)$, and the rate of $\mathrm{NO}_{3}{ }^{-}$uptake (assimilation) exceeded the rate of nitrification (Böhlke et al. 2004; Smith et al. 2006; Smith et al. submitted). Therefore, during base-flow conditions, when most measurements were done, $\mathrm{N}$ may have accumulated gradually in stream biota and sediments. This reservoir of excess autochthonous organic matter may have contributed to maintaining benthic denitrification, as indicated by local association of high $U_{\text {denit }}$ with plant beds and organic-rich sediments. Then, during short periods at irregular intervals during high-flow events, substantial amounts of this organic matter may have been removed, lowering denitrification rates while the system recovered (e.g., June 2001 in Sugar Creek).

Figure 8 illustrates two hypothetical responses of benthic denitrification rates to a high-flow event, based on observations summarized above. Because there were no continuous stream-flow data within our study reach in Sugar Creek, values of flow and $\mathrm{NO}_{3}{ }^{-}$ concentration for these calculations were taken from reported measurements before, during, and after a high-flow event just downstream at the Milford stream gage in Sugar Creek in May 1990 (USGS 2008). $\mathrm{NO}_{3}{ }^{-}$ concentration was relatively high $\left(>1,100 \mu \mathrm{mol} \mathrm{L}^{-1}\right)$ before the event, decreased rapidly during peak flow, presumably because of dilution by precipitation runoff and other low $\mathrm{NO}_{3}{ }^{-}$discharges, and then increased to its pre-event value as flow receded. In one hypothetical denitrification scenario, $U_{\text {denit }}$ was estimated from $\mathrm{NO}_{3}{ }^{-}$concentration at each point in time by using the correlation in Fig. 7 (i.e., no change in benthic properties, same as in the seasonal models). Major features of this scenario include a small decrease in $U_{\text {denit }}$ and larger increase in $v_{\mathrm{f} \text {,denit }}$ when $\mathrm{NO}_{3}{ }^{-}$was diluted at high flow, followed by recovery of $\mathrm{NO}_{3}{ }^{-}$, $U_{\text {denit }}$, and $v_{\mathrm{f} \text {,denit }}$ to near pre-event values as flow receded. The response of $k 1_{\text {denit }}$ was more complex and included a gradual increase long after the flow peaked when $\mathrm{NO}_{3}{ }^{-}$concentration, $U_{\text {denit }}$, and $v_{\mathrm{f} \text {,denit }}$ were relatively constant but depth continued to decrease. The relatively small relative change in $U_{\text {denit }}$ can be attributed to the fact that this scenario began when stream $\mathrm{NO}_{3}{ }^{-}$concentration was high (May), when the dependence of $U_{\text {denit }}$ on $\mathrm{NO}_{3}{ }^{-}$was relatively flat (Eq. 1, Fig. 7), whereas we expect $U_{\text {denit }}$ might exhibit a larger relative response to $\mathrm{NO}_{3}{ }^{-}$dilution during an event later in the year when $\mathrm{NO}_{3}{ }^{-}$concentration was lower.

In another scenario (Fig. 8), we simulated a substantial decrease in denitrification during the 
event that persisted after the event, owing to remobilization and removal (flushing) of reactive benthic organic matter. In this scenario, the initial response to the runoff event was similar to the previous one, but $U_{\text {denit }}, v_{\text {f,denit }}$, and $k 1_{\text {denit }}$ all were lower at peak flow and did not recover with the rise in $\mathrm{NO}_{3}{ }^{-}$concentration, and $k 1_{\text {denit }}$ remained low during the flow recession. In both scenarios (with measured values of $\mathrm{NO}_{3}{ }^{-}$and flow, with and without a hypothetical change in the benthic properties), the high-flow event caused hysteresis in the relation between $k 1_{\text {denit }}$ and depth (Fig. 9). If reasonable qualitatively, the flushing model highlights a potentially important difference between long-term integrated total $\mathrm{N}$ loss estimates in streams (e.g., from multi-annual total $\mathrm{N}$ load analyses) and most short-term total $\mathrm{N}$ loss measurements (e.g., from local $\mathrm{N}$ cycle studies during relatively stable low-flow conditions). The former, which corresponds to the steady-state approach used for regional spatial regression models like SPARROW (Alexander et al. 2000), may be related more confidently with long-term net loss of fixed $\mathrm{N}$ by denitrification, although non-steady-state conditions also could be a factor at inter-annual time scales.

\section{Conclusions}

Our measurements were diverse, yet they represent a compromise between spatial/temporal coverage and focused process studies. In comparison to synoptic comparisons of many streams (e.g., Mulholland et al. 2008), our study was more limited in geographic scope and may not represent processes occurring elsewhere. In comparison to controlled laboratory experiments or denitrification potential measurements (e.g., Christensen et al. 1990; Pfenning and McMahon 1996; Arnon et al. 2007; O'Connor and Hondzo 2008), our study was subject to ambiguity about the effects of individual variables. Nevertheless, with multiple visits to the same sites, and a variety of independent multi-scale measurements performed either in situ, or with relatively little disturbance of stream-sediment structure, microbial activity, and water chemistry, our study yielded a number of useful insights about stream denitrification in an important $\mathrm{NO}_{3}{ }^{-}$source area.

Our results illustrated some of the advantages of isotopic tracers for resolving $\mathrm{N}$ sources and sinks.
Low-level enrichments of ${ }^{15} \mathrm{NO}_{3}{ }^{-}$(with only minor changes in $\mathrm{NO}_{3}{ }^{-}$concentration) were used in core microcosms, benthic chambers, and at the reach scale with monitoring of both surface water and hyporheic zone profiles. In each case, measurements of ${ }^{15} \mathrm{NO}_{3}{ }^{-}$ dilution and ${ }^{15} \mathrm{~N}_{2}$ production provided information not obtainable from mass balances alone. The most direct (simultaneous) comparisons of different methods were between total $\mathrm{N}_{2}$ production and ${ }^{15} \mathrm{~N}_{2}$ production in core microcosms, and between ${ }^{15} \mathrm{~N}_{2}$ production at the reach scale, within the hyporheic zone, and in benthic chambers. Agreement of results from these comparisons provided indirect support for the methods, but more directly confirmed that surface water was the primary source of $\mathrm{NO}_{3}{ }^{-}$being denitrified and that hyporheic zone denitrification was an important component of reach-scale denitrification.

Measured denitrification rates were highly variable locally, but also revealed general patterns related to flow and $\mathrm{NO}_{3}{ }^{-}$concentration in both Sugar Creek and Iroquois River. Simple models based on these general relations were used to illustrate temporal relations between flow, $\mathrm{NO}_{3}{ }^{-}, U_{\text {denit }}, v_{\mathrm{f} \text {,denit }}$, and $k 1_{\text {denit }}$ (and hypothetically temperature) at seasonal and flow-event time scales. From the dataset as a whole, we found positive correlations between stream flow, depth, $\mathrm{NO}_{3}{ }^{-}$concentration, $\mathrm{NO}_{3}{ }^{-}$load, and benthic denitrification flux $\left(U_{\text {denit }}\right)$, but those variables were inversely correlated with denitrification rate constant $\left(k 1_{\text {denit }}\right)$ and denitrification transfer velocity $\left(v_{\mathrm{f} \text {,denit }}\right)$. Because $k 1_{\text {denit }}$ and $v_{\mathrm{f} \text {,denit }}$ are related implicitly with flow, $\mathrm{NO}_{3}{ }^{-}$concentration, and(or) $\mathrm{NO}_{3}{ }^{-}$load, it appears the simplest useful relation among these variables for modeling benthic denitrification at the reach scale (ignoring local variability) is between $\mathrm{NO}_{3}{ }^{-}$concentration and $U_{\text {denit }}$, which can be transformed to other parameters using independently available physical and chemical data. This is important because relations between stream flow, $\mathrm{NO}_{3}{ }^{-}$concentration, and $\mathrm{NO}_{3}{ }^{-}$load in different streams are variable, depending on geology, climate, land use, and other watershed characteristics affecting hydrology and biogeochemistry.

The relation between $U_{\text {denit }}$ and $\mathrm{NO}_{3}{ }^{-}$derived from our aggregated dataset incorporating temporal variations in flow and $\mathrm{NO}_{3}{ }^{-}$concentration in two streams was less than first order and could be described using either power law or saturation 
equations. Ambiguity about this relation was caused in part by local variability in rates caused by other stream and sediment characteristics, for which additional parameters and data would be needed to improve predictions. Our power law exponent was similar to one derived from spatial variations in $U_{\text {denit }}$ and $\mathrm{NO}_{3}{ }^{-}$in a recent compilation of data from a large number of sites, most of which had relatively low $\mathrm{NO}_{3}{ }^{-}$concentrations (Mulholland et al. 2008). The combined data from these studies may reflect a common relation between $U_{\text {denit }}$ and $\mathrm{NO}_{3}{ }^{-}$across a wide range of physical and chemical environments. Adding a parameter for non-linear $\mathrm{NO}_{3}{ }^{-}$concentration dependence of in-stream denitrification rates might be useful for improving both spatial and temporal simulations and mass balance regressions of $\mathrm{N}$ movement through watersheds across diverse landscapes.

Important variables missing from the current data evaluation include temperature, biologic community function (macro and micro), sediment characteristics, electron donor supply, and $\mathrm{O}_{2}$ availability, all of which likely varied spatially as well as on diel to seasonal (and interannual?) time scales. Field measurements across these variables in streams are limited and commonly contradictory. The relative lack of in situ data from winter and early spring is especially limiting in watersheds like the upper Mississippi River basin (and much of the eastern and central USA), where annual $\mathrm{NO}_{3}{ }^{-}$loads are dominated by those periods when denitrification rates are largely unknown.

Acknowledgments This paper is a product of a workshop on Denitrification Modeling Across Terrestrial, Freshwater, and Marine Systems, held November 28-30, 2006, at the Institute of Ecosystem Studies, Millbrook, New York, with support from the Denitrification Research Coordination Network of the National Science Foundation, award DEB0443439 and the Northeastern States Research Cooperative (Grant \# 02-CA11242343-105). The research was supported in part by the US Department of Agriculture Cooperative State Research, Education and Extension Service (National Research Initiative Competitive Grants Program in Watershed Processes and Water Resources), NSF award EAR0408744, and the US Geological Survey (USGS) National Research Program in Water Resources. Assistance in the field and laboratory was provided by many people including Karen Casciotti, Joel Detty, Michael Doughten, Perry Draper, David Dupre, Janet Hannon, Charles Hart, JoAnn Holloway, Jonah Jackson, Julie Kirshtein, Ronald Knapp, Stan Mroczkowski, Eric Nemeth, Jessica Newlin, Deb Repert, Kevin Richards, Durelle Scott, Craig Tobias, Peggy Widman. Helpful comments on earlier versions of the manuscript were made by Frank Triska, Benjamin O'Connor, and three anonymous reviewers. Use of trade or product names in this paper is for identification purposes only and does not constitute endorsement by the USGS.

Open Access This article is distributed under the terms of the Creative Commons Attribution Noncommercial License which permits any noncommercial use, distribution, and reproduction in any medium, provided the original author(s) and source are credited.

\section{References}

Alexander RB, Smith RA, Schwartz GE (2000) Effect of stream channel size on the delivery of nitrogen to the Gulf of Mexico. Nature 403:758-761

Alexander RB, Boyer EW, Smith RA, Schwarz GE, Moore RB (2007) The role of headwater streams in downstream water quality. J Am Water Resour Assoc 43:41-59

Alexander RB, Smith RA, Schwarz GE, Boyer EW, Nolan JV, Brakebill JW (2008a) Differences in phosphorus and nitrogen delivery to the Gulf of Mexico from the Mississippi River basin. Environ Sci Technol 42:822-830

Alexander RB, Böhlke JK, Boyer EW, David M, Harvey JW, Mulholland PJ, Seitzinger SP, Tobias CR, Tonitto C, Wollheim WM (2008b) Dynamic modeling of nitrogen losses in river networks unravels the coupled effects of hydrological and biogeochemical processes. Biogeochemistry (this issue). doi:10.1007/s10533-008-9274-8

Antweiler RC, Smith RL, Voytek MA, Böhlke JK (2005a) Water-quality data from two agricultural drainage basins in northwestern Indiana and northeastern Illinois: II. Diel data, 1999-2001. U.S. Geological Survey Open-File Report 2005-1053, Boulder

Antweiler RC, Smith RL, Voytek MA, Böhlke JK, Dupre DH (2005b) Water-quality data from two agricultural drainage basins in northwestern Indiana and northeastern Illinois: III. Biweekly data, 2000-2002. U.S. Geological Survey Open-File Report 2005-1197, Boulder

Antweiler RC, Smith RL, Voytek MA, Böhlke JK, Richards KD (2005c) Water-quality data from two agricultural drainage basins in northwestern Indiana and northeastern Illinois: I. Lagrangian and synoptic data, 1999-2002. U.S. Geological Survey Open-File Report 2004-1317, Boulder

Arango CP, Tank JL, Schaller JL, Royer TV, Bernot MJ, David MB (2007) Benthic organic carbon influences denitrification in streams with high nitrate concentration. Freshw Biol 52:1210-1222

Arnon S, Gray KA, Packman AI (2007) Biophysicochemical process coupling controls nitrate use by benthic biofilms. Limnol Oceanogr 52:1665-1671

Asher W, Wanninkhof R (1998) Transient tracers and air-sea gas transfer. J Geophys Res 103-C:15939-15958

Bernot MJ, Dodds WK (2003) Nitrogen retention, removal, and saturation in lotic ecosystems. Ecosystems 8:442-453

Birgand F, Skaggs RW, Chescheir GM, Gilliam JW (2007) Nitrogen removal in streams of agricultural catchmentsa literature review. Crit Rev Environ Sci Technol 37: $381-487$ 
Böhlke JK, Harvey JW, Voytek MA (2004) Reach-scale isotope tracer experiment to quantify denitrification and related processes in a nitrate-rich stream, midcontinent United States. Limnol Oceanogr 49:821-838

Böhlke JK, Smith RL, Hannon JE (2007) Isotopic analysis of N and $\mathrm{O}$ in nitrite and nitrate by sequential selective bacterial reduction to $\mathrm{N}_{2} \mathrm{O}$. Anal Chem 79:5888-5895

Boyer EW, Alexander RB, Parton WJ, Li CS, Butterbach-Bahl K, Donner SD, Skaggs RW (2006) Modeling denitrification in terrestrial and aquatic ecosystems at regional scales. Ecol Appl 16:2123-2142

Christensen PB, Nielsen LP, Sorensen J, Revsbech NP (1990) Denitrification in nitrate-rich streams: diurnal and seasonal variation related to benthic oxygen metabolism. Limnol Oceanogr 35:640-651

Cornwell JC, Kemp WM, Kana TM (1999) Denitrification in coastal ecosystems: methods, environmental controls, and ecosystem level controls, a review. Aquat Ecol 33:41-54

Donner SD, Kuchank CJ, Foley JA (2004) Impact of changing land use practices on nitrate export by the Mississippi River. Glob Biogeochem Cycles 18:GB1028. doi:10.1029/ 2003GB002093:1-21

Garcia-Ruiz R, Pattinson SN, Whitton BA (1998a) Denitrification in river sediments: relationship between process rate and properties of water and sediment. Freshw Biol 39:467-476

Garcia-Ruiz R, Pattinson SN, Whitton BA (1998b) Kinetic parameters of denitrification in a river continuum. Appl Environ Microbiol 64:2533-2538

Goolsby DA, Battaglin WA, Lawrence GB, Artz RS, Aulenbach BT, Hooper RP, Keeney DR, Stensland GJ (1999) Flux and sources of nutrients in the Mississippi-Atchafalaya River basin. Topic 3 report for the integrated assessment on hypoxia in the Gulf of Mexico. NOAA Coastal Ocean Program Decision Analysis Series No. 17, NOAA Coastal Ocean Program, Silver Spring

Goolsby DA, Battaglin WA, Kendall C, McMahon PB, Clark GM, Campbell DH, Böhlke JK, Doughten MW (2000) Evidence for conservative transport of nitrate in the Mississippi River (abstract). EOS Trans Am Geophys Union 81:S189

Groffman PM, Altabet MA, Böhlke JK, Butterbach-Bahl K, David MB, Giblin AE, Kana TM, Nielsen LP, Firestone MK, Voytek MA (2006) Methods for measuring denitrification: diverse approaches to a difficult problem. Ecol Appl 16:2091-2122

Harvey JW, Fuller CC (1998) Effect of enhanced manganese oxidation in the hyporheic zone on basin-scale geochemical mass balance. Water Resour Res 34:623-636

Harvey JW, Böhlke JK, Voytek MA (2005) Comparison of whole-stream and hyporheic-zone estimates of denitrification determined simultaneously during an isotope tracer injection in a nitrate-rich stream (abstract). EOS Trans Am Geophys Union 86(18):235 (Joint Assembly Supplement, Abstract NB223E-205)

Herbert RA, Nedwell DB (1990) Role of environmental factors in regulating nitrate respiration in intertidal sediments. In: Revsbach NP, Sorensen J (eds) Denitrification in soil and sediment. Plenum, New York, pp 77-90
Herrman KS, Bouchard V, Moore RH (2008) Factors affecting denitrification in agricultural headwater streams in northeast Ohio, USA. Hydrobiologia 598:305-314

Howarth RW, Billen G, Swaney D, Townsend A, Jaworski N, Lajtha K, Downing JA, Elmgren R, Caraco N, Jordan T, Berendse F, Freney J, Kudeyarov V, Murdoch P, Zhao-Liang Z (1996) Regional nitrogen budgets and riverine $\mathrm{N} \& \mathrm{P}$ fluxes for the drainages to the North Atlantic Ocean: natural and human influences. Biogeochemistry 35:75-139

Jenkins MC, Kemp WM (1984) The coupling of nitrification and denitrification in two estuarine sediments. Limnol Oceanogr 29:609-619

Kana TM, Sullivan MB, Cornwell JC, Groszkowski KM (1998) Denitrification in estuarine sediments determined by membrane inlet mass spectrometry. Limnol Oceanogr 43:334-339

Laursen AE, Seitzinger SP (2002) Measurement of denitrification in rivers: an integrated, whole reach approach. Hydrobiologia 485:67-81

Laursen AE, Seitzinger SP (2005) Limitations to measuring riverine denitrification at the whole reach scale: effects of channel geometry, wind velocity, sampling interval, and temperature inputs of $\mathrm{N}_{2}$-enriched groundwater. Hydrobiologia 545:225-236

Leopold LB, Maddock TJ (1953) The hydraulic geometry of stream channels and some physiographic implications. U.S. Geological Survey Professional Paper 252, Reston

Mulholland PJ, Helton AM, Poole GC, Hall ROJ, Hamilton SK, Peterson BJ, Tank JL, Ashkenaas LR, Cooper LW, Dahm CN, Doods WK, Findley SEG, Gregory SV, Grimm NB, Johnson SL, McDowell WH, Meyer JL, Valett HM, Webster JR, Arango CP, Bealieu JJ, Bernot MJ, Burgin AJ, Crenshaw CL, Johnson LT, Niederlehner BR, O’Brien JM, Potter JD, Sheibley RW, Sobota DJ, Thomas SM (2008) Stream denitrification across biomes and its response to anthropogenic nitrate loading. Nature 452:202-205

O'Brien JM, Dodds WK, Wilson KC, Murdock JN, Eichmiller $\mathrm{J}$ (2007) The saturation of $\mathrm{N}$ cycling in Central Plains streams: ${ }^{15} \mathrm{~N}$ experiments across a broad gradient of nitrate concentrations. Biogeochemistry 84:31-49

O'Connor BL, Hondzo M (2008) Enhancement and inhibition of denitrification by fluid-flow and dissolved oxygen flux to stream sediments. Environ Sci Technol 42:119-125

O'Connor BL, Hondzo M, Dobraca D, LaPara TM, Finlay JC, Brezonik PL (2006) Quantity-activity relationship of denitrifying bacteria and environmental scaling in streams of a forested watershed. J Geophys Res Biogeosci 111:G04014. doi:10.1029/2006JG000254:1-13

Opdyke MR, David MB (2007) Response of sediment denitrification rates to environmental variables in streams heavily impacted by agriculture. J Freshw Ecol 22:371-382

Payn RA, Webster JR, Mulholland PJ, Valett HM, Dodds WK (2005) Estimation of stream nutrient uptake from nutrient addition experiments. Limnol Oceanogr Methods 3:174182

Pfenning KS, McMahon PB (1996) Effect of nitrate, carbon, and temperature on potential denitrification rates in nitrate-rich riverbed sediments. J Hydrol 187:283-295 
Pina-Ochoa E, Alvarez-Cobelas M (2006) Denitrification in aquatic environments: a cross-system analysis. Biogeochemistry 81:111-130

Royer TV, Tank JL, David MB (2004) Transport and fate of nitrate in headwater agricultural streams in Illinois. $\mathrm{J}$ Environ Qual 33:1296-1304

Runkel RL (1998) One-dimensional transport with inflow and storage (OTIS): a solute transport model for streams and rivers. U.S. Geological Survey Water Resources Investigation Report 98-4018, Denver

Runkel RL (2007) Toward a transport-based analysis of nutrient spiraling and uptake in streams. Limnol Oceanogr Methods 5:50-62

Rysgaard S, Risgaard-Petersen N, Sloth NP, Jensen K, Nielsen LP (1994) Oxygen regulation of nitrification and denitrification in sediments. Limnol Oceanogr 39:1643-1652

Seitzinger SP, Styles RV, Boyer EW, Alexander RB, Billen G, Howarth R, Mayer B, Van Breeman N (2002) Nitrogen retention in rivers: model development and application to watersheds in the eastern U.S. Biogeochemistry 57(58):199-237

Seitzinger SP, Harrison J, Böhlke JK, Bouwman AF, Lowrance RR, Peterson BJ, Tobias CR, van Drecht G (2006) Denitrification across landscapes and waterscapes: a synthesis. Ecol Appl 16:2064-2090

Smith LK, Voytek MA, Böhlke JK, Harvey JW (2006) Denitrification in nitrate-rich streams: application of $\mathrm{N}_{2}$ : $A r$ and ${ }^{15} \mathrm{~N}$ tracer methods in intact cores. Ecol Appl 16:2191-2207

Smith RL, Böhlke JK, Repert DA, Hart CP (2005) Denitrification rates in a midwestern stream containing high nitrate: in situ assessment using tracers in dome-shaped incubation chambers (abstract). EOS Trans Am Geophys Union 86:JA229

Smith RL, Böhlke JK, Repert DA, Hart CP (submitted) Nitrification and denitrification in a midwestern stream containing high nitrate: in situ assessment using tracers in dome-shaped incubation chambers

Stream-Solute-Workshop (1990) Concepts and methods for assessing solute dynamics in stream ecosystems. J North Am Benthol Soc 9:95-119

Tobias CR, Böhlke JK, Harvey JW (2007) The oxygen-18 isotope approach for measuring aquatic metabolism in high-productivity waters. Limnol Oceanogr 52:14391453

Tobias CR, Böhlke JK, Harvey JW, Busenberg E (submitted) A simple technique for continuous measurement of timevariable gas transfer in surface waters. Limnol Oceanogr Methods

USGS (2008) Stream-flow and water quality data. U.S. Geological Survey, National Water Information System. http:// waterdata.usgs.gov/nwis/qw, Reston

Voytek MA, Harvey JW, Smith LK, Smith RL, Böhlke JK (2001) Patch-scale controls on denitrification in stream bed sediments (abstract). EOS Trans Am Geophys Union 82:F353

Wollheim WM, Vörösmarty CJ, Peterson BJ, Seitzinger SP, Hopkinson CS (2006) Relationship between river size and nutrient removal. Geophys Res Lett 33:L06410. doi: 10.129/2006GL025845:1-4 